Article

\title{
An Experimental Investigation of Interaction between Andesite and Hyperacidic Volcanic Lake Water
}

\author{
Vincent van Hinsberg ${ }^{1, *}$, Kim Berlo $^{1}$ and Jacob Lowenstern ${ }^{2}$ \\ 1 Department of Earth and Planetary Sciences, McGill University, 3450 University Street, \\ Montréal, QC H3A0E8, Canada; Kim.Berlo@mcgill.ca \\ 2 USGS Cascades Volcano Observatory, Vancouver, WA 98683, USA; jlwnstrn@usgs.gov \\ * Correspondence: V.J.vanHinsberg@gmx.net
}

Received: 28 November 2019; Accepted: 17 January 2020; Published: 22 January 2020

\begin{abstract}
Alteration in magmatic-hydrothermal systems leads to distinct changes in rock texture and mineralogy, and a strong redistribution of elements between fluid and rock. Here, we experimentally interacted andesite scoria with hyperacidic, high-sulfidation style fluids from Kawah Ijen volcano (Indonesia) at 25 and $100{ }^{\circ} \mathrm{C}$, seeking to reproduce the textures observed in natural samples from this volcano, and to understand the element fluxes that accompany alteration. The susceptibility to alteration in the experiments is $\mathrm{Cu}-\mathrm{Fe}$-sulphide $>$ calcic plagioclase $>$ pyroxene $>$ titano-magnetite $>$ sodic plagioclase, with complete preservation of glass. Silicate minerals alter to opaline silica, and gypsum, barite and a $\mathrm{Zr}$-phase precipitate. The selective alteration of the phenocryst minerals results in a preferential release of compatible elements, as the glass is the main incompatible element host. The experiments reproduce the alteration textures of the natural samples, including the preservation of glass, but the predicted compatible over incompatible element enrichment in the alteration element flux is not observed in the natural setting. This suggests that alteration at Kawah Ijen is dominated by lithologies that lack abundant glass, in particular lava flows where the glass has devitrified, despite these lava flows having a lower surface area compared to scoria.
\end{abstract}

Keywords: water-rock interaction; alteration; Kawah Ijen; Banyu Pahit; hyperacidic water; alteration flux; alteration experiment

\section{Introduction}

Water-rock interaction is a powerful mechanism for element segregation that can lead to formation of economic element enrichments by both selective leaching and residual enrichment. Igneous systems are particularly interesting in this respect as these can host large-scale hydrothermal systems with development of multiple distinct alteration zones radiating out with the temperature gradient [1,2]. These systems are hosts to several types of major mineralisations, including porphyry and epithermal deposits [2,3], testifying to the efficacy of element segregation during water-rock interaction. The selective element mobilisation results in changes in the mineralogy and texture of the rock and the composition of its constituent phases [4,5]. However, the outcome is highly sensitive to the fluid composition and system parameters including $T, P, \mathrm{pH}, \mathrm{S}$ activity, and $f \mathrm{O}_{2}$, which control to solubility of elements in the fluid, the susceptibility of different minerals to alteration, and the secondary mineralogy [6,7]. In most rock alteration settings, the fluid phase is poorly preserved, if at all, and information on the composition of the fluid needs to be determined from the chemistry of the phases that formed from it. The common incongruent dissolution of minerals during alteration and the non-attainment of equilibrium owing to kinetic factors are further complications which can make interpretation of natural alteration products ambiguous. 
In this study, we experimentally investigated the textural and compositional changes in an igneous rock reacting with volcanogenic, high-sulphidation style fluid. Such fluids are highly acidic and oxidized, found in the shallow parts of magmatic systems, and are implicated in the formation of $\mathrm{Cu}-\mathrm{Au}$ and $\mathrm{Ag}-\mathrm{Pb}$ ore deposits [2,3,7-9]. High-sulphidation style fluids also occur on the surface in crater lakes and volcanogenic acid seepage [10]. Here, we investigate a porous andesite interacting with hyperacidic, high-sulphidation brine from the Kawah Ijen crater lake (Indonesia). This study was motivated by the discovery of abundant opal-rich pumice and scoria in phreato-magmatic deposits of the Kawah Ijen 1817 eruption [11]. This eruption involved interaction with, and eventual expulsion of, a hyperacidic lake with a composition similar to that found in high-sulphidation hydrothermal systems [12]. The eruption produced deposits ranging from phreatic to phreato-magmatic to magmatic [13], with opal-rich material found in the proximal phreatic and phreato-magmatic fall deposits, lahar and mudflows. Lowenstern et al. (2018) showed that the clasts in these deposits contain pristine magmatic glass enclosing opal pseudomorphs after plagioclase and pyroxene phenocrysts [11]. This raised questions about the relative timing of alteration and magmatism and the conditions required to create the observed textures (see Lowenstern el al., 2018 [11] for more details). Here, we sought to experimentally replicate interaction between 1817 unaltered scoria and hyperacidic lake water with the aims of understanding the alteration process and resulting element fluxes, as well as any differences between the batch alteration of our experiments and the open-system alteration taking place at Kawah Ijen.

\section{The Kawah Ijen-Banyu Pahit System}

Kawah Ijen volcano is a small active stratovolcano located on the southeastern rim of the Ijen caldera complex in East Java, Indonesia (Figure 1). The volcano has emitted a variety of magmatic to phreatic deposits, including basaltic to dacitic lava flows and fall deposits, and pyroclastic flow and lahar deposits [13-17]. A $27 \mathrm{Mm}^{3}$ lake of hyperacidic $(\mathrm{pH} \approx 0)$, warm $\left(>35^{\circ} \mathrm{C}\right)$, concentrated fluid ( 100 $\mathrm{g} \mathrm{kg}^{-1} \mathrm{TDS}, 22 \mathrm{~g} \mathrm{~kg}^{-1} \mathrm{Cl}, 64 \mathrm{~g} \mathrm{~kg}^{-1} \mathrm{SO}_{4}$ ) occupies the volcano's summit crater [17-22]. The volcano last erupted in 1817 in a phreato-magmatic event, with more recent activity limited to phreatic and steam explosions, and passive degassing from a fumarolic zone on the eastern lake shore [13,23-26]. Lake and deeper subsurface hyperacidic fluids emerge on the western flank of the volcano in a series of seepage springs that converge to form the Banyu Pahit river (Figure 1). The spring waters have a $\mathrm{pH} \approx 0$, but the $\mathrm{pH}$ of the river rises as it mixes with groundwater and neutral rivers, and interacts with its riverbed [14,27-29]. Nonetheless, the river exits the caldera ca. $18 \mathrm{~km}$ downstream from the lake with a $\mathrm{pH}$ of 4.5 [28], and is still acidic where used in irrigation on the Asambagus plain of the north-east Java coast, with detrimental effects for health and crop yields [30,31].

Water-rock interaction at Kawah Ijen takes place in the subsurface hydrothermal system, in and around the lake, and along the Banyu Pahit river [12,14,18,20,32]. In-situ, active alteration can be observed in the Banyu Pahit riverbed and is particularly well exposed where the river flows on a lava flow downstream of the lowermost seepage area. Progressive alteration zones are observed from unaltered lava above the water level, to greyish-purple partially altered material in the splash zone, and fully altered grey to white friable material below the water level (similar to the scoria alteration zones of Figure 1b). The textural and compositional changes that accompany this alteration are described in detail in van Hinsberg et al., 2010 [14,32]. In the uppermost section of the river valley (Figure 1c), the river flows mostly on phreato-magmatic fall, lahar and mudflow deposits, including an up to $20 \mathrm{~m}$ thick sequence related to the 1817 eruption. The latter includes abundant dark grey scoria and beige pumice, both andesite in bulk composition. The denser scoria shows progressive alteration from the rim inward (Figure 1b), whereas the pumice clasts are commonly altered throughout to opaline material, but with the complete preservation of glass (see Lowenstern et al., 2018 [11] for details). 

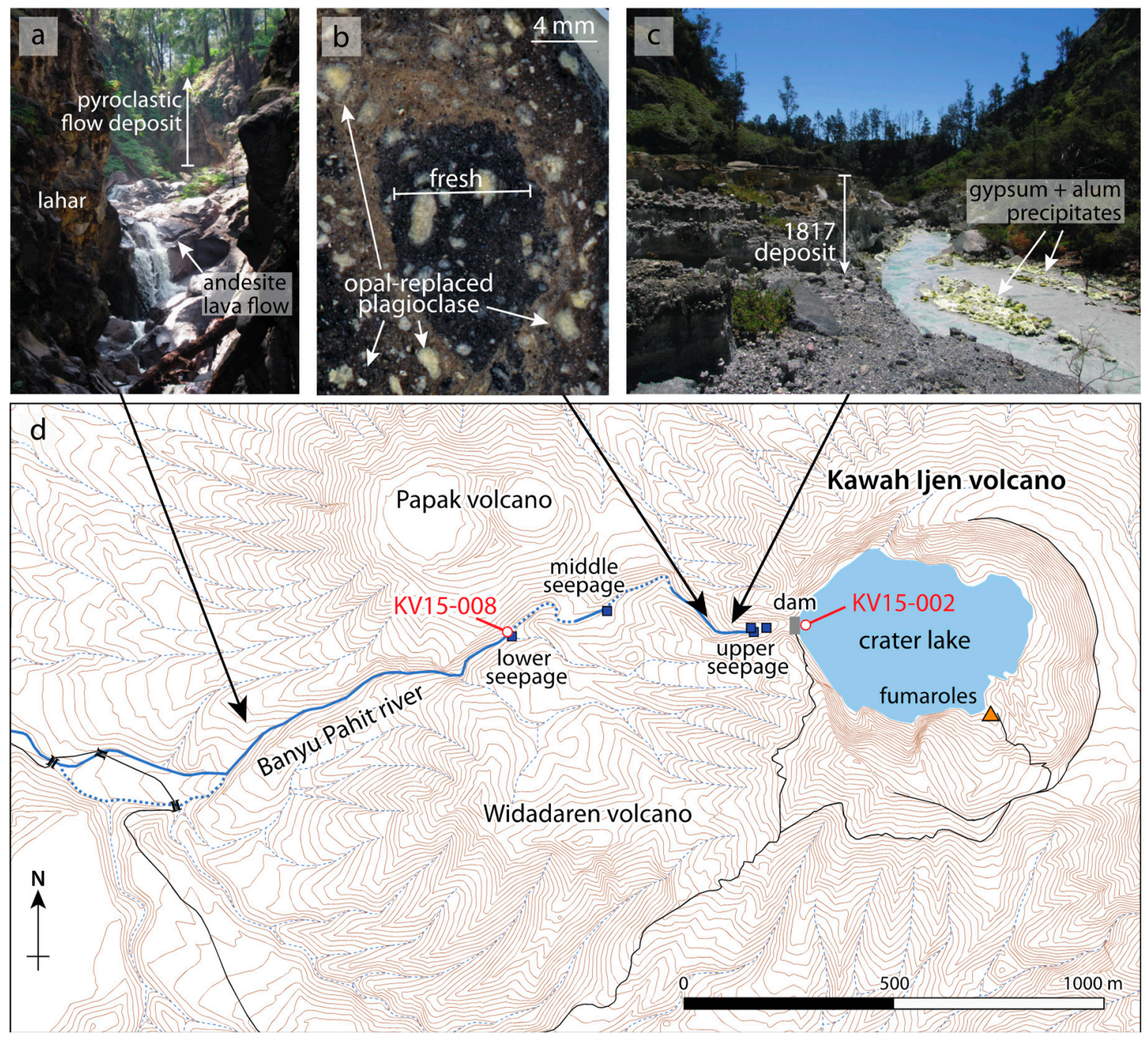

Figure 1. Topographic map of Kawah Ijen volcano and the upstream Banyu Pahit river, showing the locations of acid-water seepage springs and samples used in this study (d). The river flows on phreatic and phreato-magmatic deposits in its uppermost valley (c) including those from the 1817 eruption, whereas it flows on an andesite lava flow further downstream in a deeply incised steep-sided valley with lahar, pyroclastic flow, mudflow and fall deposits exposed in the valley walls (a). 1817 Scoria in contact with the hyperacidic river water alter progressively from the rim of the clast inward (b), observed by a change in colour and the progressive replacement of plagioclase by glassy opal.

Opaline silica is the dominant alteration product in all settings of Kawah Ijen alteration, and results from incongruent dissolution of the silicate minerals. Plagioclase alteration follows compositional zoning with preferential alteration of anorthite-rich (An-rich) zones, whereas pyroxene alters along fractures regardless of zoning [11,32]. Two styles of alteration are observed for the titano-magnetite phenocrysts. Titano-magnetite grains with ülvospinel exsolution lamellae, mainly found in crystalline lavaflows show preferential dissolution of magnetite-rich domains, leaving a porous network of the ülvospinel lamellae that eventually disintegrate and form a void (Figure 4e,f in [32]), whereas congruent dissolution is observed for titano-magnetite grains that lack exsolution. Altered rocks from the subsurface hydrothermal system, brought to the surface in eruptions, contain precipitates of barite, cristobalite and pyrite, and veins of alunite, whereas altered samples from the lake and river contain minor jarosite and plumboan barite. Based on an in-situ alteration sequence exposed in the Banyu Pahit riverbed, van Hinsberg et al. (2010) calculated that progressive alteration leads to near-congruous transfer of the rock's elements to the fluid, leaving an opaline silica residue enriched in $\mathrm{Pb}, \mathrm{Sn}$ and 
Sb [14]. Delmelle and Bernard (1994) calculated a similar near-complete rock leaching for the lake [18]. The alteration element release matches the changes in Banyu Pahit river water as it flows downstream and interacts with the andesite lava that forms the valley floor. However, mass balance indicates that alteration cannot be limited to the lavaflow as its incision is insufficient to match the element uptake by the river [14]. Alteration must include significant material washed into the river, in agreement with its deeply incised, steep-sided valley (Figure 1a).

\section{Materials and Methods}

Experiments were conducted by interacting trimmed angular pieces of unaltered Kawah Ijen andesitic scoria (sample KV15-008), with approximate dimensions of $10 \times 3 \times 3 \mathrm{~mm}\left(551 \mathrm{mg} 25^{\circ} \mathrm{C}\right.$ run, $646 \mathrm{mg} 100{ }^{\circ} \mathrm{C}$ run), with $16.25 \mathrm{~g}$ of hyperacidic yellow-green Kawah Ijen lake water (sample KV15-002). Experiments were conducted at 25 and $100{ }^{\circ} \mathrm{C}$ (experiments WRI-25C and WRI-100C), which brackets the measured lake temperature variability of 25 to $50{ }^{\circ} \mathrm{C}$ [13]. The lake water was sampled in 2015 at the western shore of the lake (Figure 1d), filtered on-site though a $0.45 \mu \mathrm{m}$ disposable filter, and stored in an acid-cleaned high-density poly-ethylene (HPDE) bottle with conical cap to exclude air. The scoria is a juvenile magmatic clast erupted in 1817 and this scoria is an important component of the material in the uppermost Banyu Pahit river valley where it interacts with the spring and river waters (Figure 1c). The surfaces of the pieces were cleaned by grinding, and washing in nano-pure water followed by ethanol in an ultrasonic bath. Experiments were run at saturated vapour pressure in welded glass reaction vessels at room temperature and $100{ }^{\circ} \mathrm{C}$ for 42 days. Room temperature was $25 \pm 5{ }^{\circ} \mathrm{C}$ during this period. The $100{ }^{\circ} \mathrm{C}$ experiment was run in a forced circulating air oven with temperature maintained to within $2{ }^{\circ} \mathrm{C}$ (monitored by a type-K thermocouple attached to one of the experiments). The vessels were gently agitated once a week to homogenize the fluid.

At the end of the experiment, the vessels were weighed and compared to their starting mass in order to verify that they had remained sealed. No mass loss was observed. The fluid was extracted with a pipette (at $95^{\circ} \mathrm{C}$ for the $100{ }^{\circ} \mathrm{C}$ run) and stored in a teflon (PFA) container. Minor condensate was observed in both reactors above the fluid level. We did not manage to extract this, as we did not want to risk fragmenting the altered rock sample by the agitation needed to merge this condensate with the fluid. The condensate represents water vapour, and is therefore highly dilute compared to the experimental fluid. Its loss from the run product fluid will thus result in a small overestimation of the concentration of this fluid. The andesite was rinsed in distilled water, dried in air, sectioned through the middle, embedded in resin, and polished for imaging and analyses. The fluid samples were diluted with an ultrapure $5 \% \mathrm{HNO}_{3}$ solution and analysed for major elements by Inductively Coupled Plasma Optical Emission Spectrometry (ICP-OES, Thermo Fisher Scientific iCAP 6500) and for trace elements by Inductively Coupled Plasma Mass Spectrometry (ICP-MS Thermo Finnigan iCAP Qc), both at McGill University (Montréal, QC, Canada). Given the extreme matrix of these fluids, ICP calibration standards were matrix-matched by addition of ICP-MS grade multi-element standards to a Banyu Pahit river sample (KV14-201) diluted to the same level as the unknowns. The starting scoria and solid run products were investigated using backscattered electron imaging and energy dispersive spectrometry (EDS) on a PhenomXL desktop scanning electron microscope (SEM) at McGill University (Montréal, QC, Canada) and by wavelength dispersive spectrometry (WDS) on a JEOL 8200 electron probe micro analyzer (EPMA) at the University of Copenhagen (Copenhagen, Denmark). Operating conditions for the EPMA were a 15kV accelerating voltage, $15 \mathrm{nA}$ beam current and $5 \mu \mathrm{m}$ defocussed beam, using natural and synthetic minerals to calibrate. Mineral and glass reference materials were analysed at regular intervals to check for drift and assess accuracy and precision. The bulk composition of the andesite scoria was determined by ICP-OES and ICP-MS on dissolved lithium-borate flux-digested rock powder and aqua-regia digested sample aliquots. The total sulphur content was determined by LECO combustion analysis on a sample split. These analyses were conducted by AcmeLabs/Bureau Veritas Minerals (analytical procedures LF200, AQ200 and TC000; Vancouver, BC, Canada). 
The relative accuracy of the EPMA-WDS analyses is $\mathrm{SiO}_{2}-0.1 \%, \mathrm{TiO}_{2}-0.2 \%, \mathrm{Al}_{2} \mathrm{O}_{3}-0.9 \%$, $\mathrm{MgO}-0.7 \%, \mathrm{FeO}-1.7 \%, \mathrm{CaO}-2.5 \%, \mathrm{Na}_{2} \mathrm{O}-0.3 \%, \mathrm{~K}_{2} \mathrm{O}-0.1 \%, \mathrm{SO}_{3}-45 \%, \mathrm{Cl}-9 \%, \mathrm{~F}-43 \%$, and $4 \%$ for $\mathrm{P}_{2} \mathrm{O}_{5}$, and the precision, in absolute $\mathrm{wt} \%$, is $\mathrm{SiO}_{2}-0.3, \mathrm{TiO}_{2}-0.06, \mathrm{Al}_{2} \mathrm{O}_{3}-0.1, \mathrm{MgO}-0.05$, $\mathrm{FeO}-0.07, \mathrm{CaO}-0.03, \mathrm{Na}_{2} \mathrm{O}-0.03, \mathrm{~K}_{2} \mathrm{O}-0.02, \mathrm{SO}_{3}-0.01, \mathrm{Cl}-0.01, \mathrm{~F}-0.06$, and 0.02 for $\mathrm{P}_{2} \mathrm{O}_{5}$. The precision of the fluid analyses, as determined from duplicates, is better than $5 \%$ relative for the ICP-OES, except for Fe (8\%) and $\mathrm{Mg}(7 \%)$ and better than 1\% relative for the ICP-MS, except for Cu (2.7\%), Se (2.9\%), Ag (8\%), Cs (1.1\%), Ba (4.6\%), Hf (1.1\%), Ta (11\%), W (10\%), and Bi $(1.4 \%)$. The accuracy of the andesite bulk-rock digest analysis in relative deviation, based on certified reference materials GS311-1, GS910-4, DS10, OREAS45, SO-18 and SO-19, is within 5\%, except for Ta and Mo (7\%), Rb, Nd, Gd and As (8\%), Be (29\%), and Se (80\%). Bulk-rock sample heterogeneity, as determined from duplicate analyses and given in relative standard deviation, is less than $5 \%$ for $\mathrm{Cr}, \mathrm{Co}, \mathrm{Cu}, \mathrm{V}, \mathrm{Pr}$, $\mathrm{Nd}, \mathrm{Tb}, \mathrm{Dy}, \mathrm{Er}, \mathrm{Yb}$, Lu and $\mathrm{Nb}$, less than 10\% for Ni, Zn, As, Th, Ce, Eu and Ho, 15\% for Ta and Pb, 20\% for Mo, $28 \%$ for $\mathrm{S}, 67 \%$ for Be and Cs, and less than $2 \%$ for the major elements.

\section{Results}

The starting andesite is similar in composition to Kawah Ijen andesites reported earlier and falls on the Kawah Ijen magmatic fractionation trend [11,14-16]. It consists of phenocrysts of plagioclase, clinopyroxene, orthopyroxene and titano-magnetite in a matrix of glass with vesicles (Figure 2). Microlites are rare. Accessory apatite is common, and micron-sized, spherical $\mathrm{Cu}-\mathrm{Fe}-\mathrm{S}$ globules were observed in glass and as inclusions in titano-magnetite. The plagioclase and pyroxene phenocrysts are zoned (Figure $2 b, c)$, with the plagioclase showing normal, reversed, oscillatory and patchy zoning. A diversity of zoning sequences is present, suggesting multiple sources for the plagioclase phenocrysts. The contacts between phenocrysts and matrix glass are sharp and clean, and no fractures are apparent on these contacts (e.g., Figure 2c). There is no sign of any alteration or weathering of the andesite or its constituent phases.

The run products consisted of the rock fragment and a yellow-green fluid. The fluid was transparent and lacked suspended particles. The colour of the $100{ }^{\circ} \mathrm{C}$ fluid was markedly darker than that of the $25^{\circ} \mathrm{C}$ and starting fluids. Small (up to mm-sized) transparent colourless needles of gypsum were present in the $100{ }^{\circ} \mathrm{C}$ experiment, and these were already observed at four weeks when the experiment was agitated during the run. We did not specifically look for precipitates during agitation, so it possible that the precipitates appeared earlier in the experimental run duration. The rock fragment showed no visual changes for the $25{ }^{\circ} \mathrm{C}$ experiment, but it was rounded, porous, lighter in colour, and friable after the $100{ }^{\circ} \mathrm{C}$ run.

An alteration zone can be recognized in the back-scattered electron images for both the 25 and $100{ }^{\circ} \mathrm{C}$ samples. This only affects the outermost rim of the $25^{\circ} \mathrm{C}$ sample, whereas the $100{ }^{\circ} \mathrm{C}$ shows alteration throughout. Alteration progresses inward from the surface and outward from fractures (Figure 3). The alteration textures in the 25 and $100{ }^{\circ} \mathrm{C}$ samples are similar, but better developed and more pervasive at the higher temperature. Whereas pristine phenocrysts are still abundant in the core of the $25^{\circ} \mathrm{C}$ experiment, phenocrysts are altered throughout at $100{ }^{\circ} \mathrm{C}$, although alteration intensity varies, and relics of the original mineral are still present. Alteration has therefore not gone to completion in either experiment. 


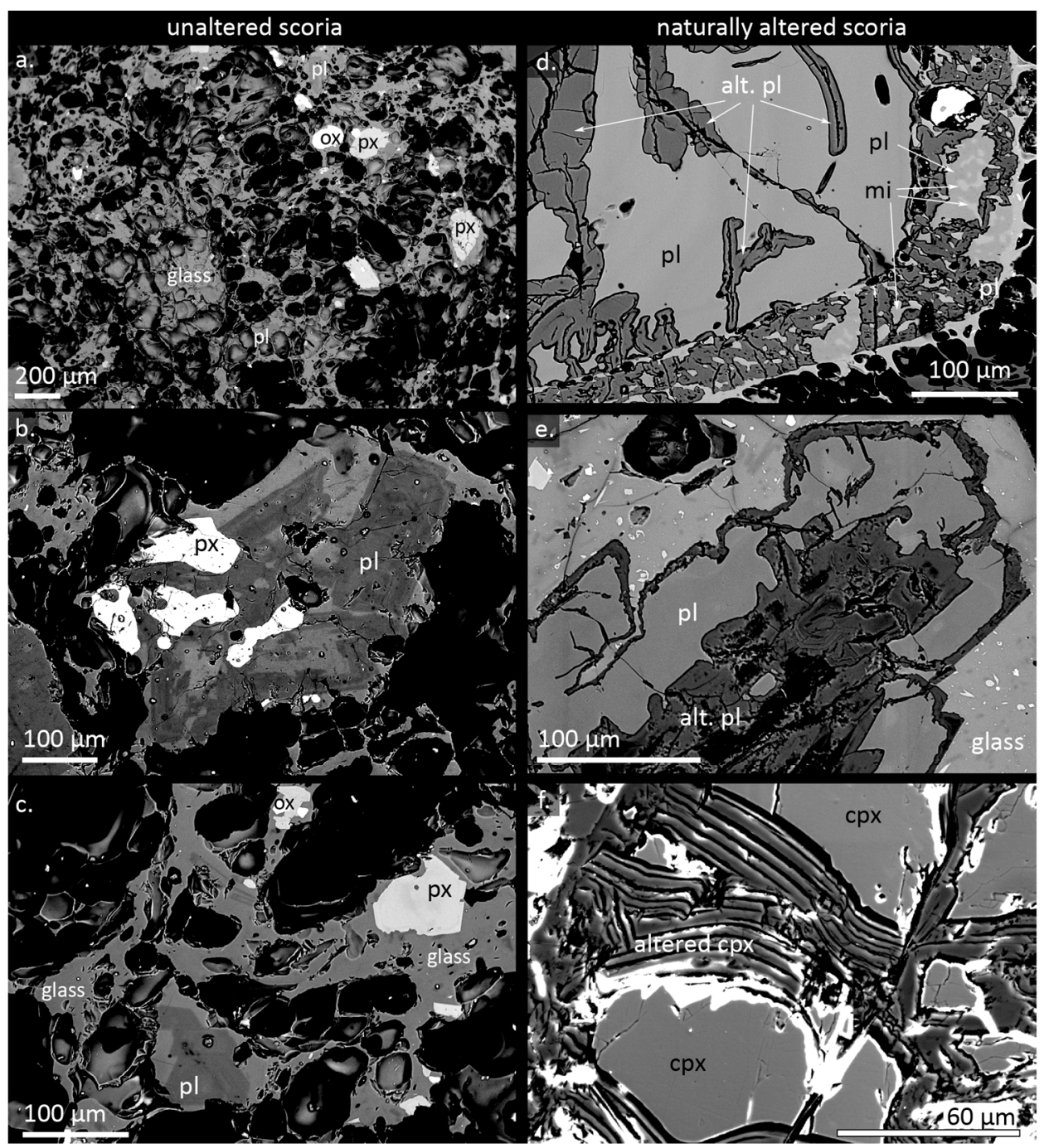

Figure 2. Back-scattered electron images of the starting andesite scoria (a-c) and a naturally altered scoria from the same eruption (d-f). (a) Overview showing phenocrysts of plagioclase, clinopyroxene and titano-magnetite in a porous, glassy matrix. (b) Zoned plagioclase phenocryst cluster with clinopyroxene. (c) Sharp, angular boundaries between phenocrysts and matrix glass. (d) Partially altered plagioclase with preservation of melt inclusions (mi) and matrix melt. The plagioclase has been altered to opaline silica. (e) Plagioclase with altered rim and core showing the strong control of compositional zoning on alteration. (f) Typical alteration texture of clinopyroxene with layered appearance of the opaline silica alteration product. Abbreviations used are pl-plagioclase; ox-oxide; px-pyroxene; cpx-clinopyroxene; alt-altered; mi-melt inclusion. 

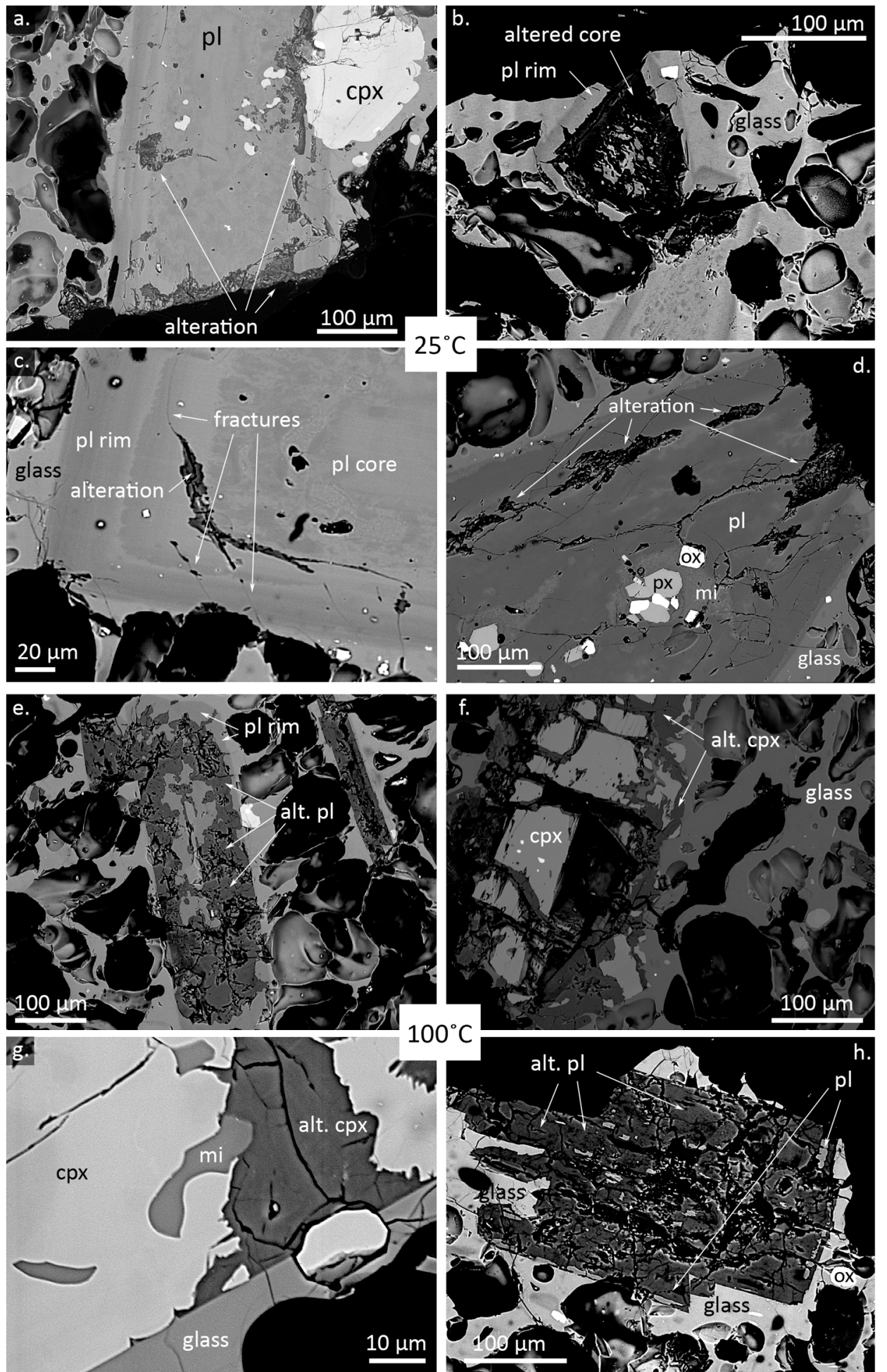

Figure 3. Back-scattered electron images of experimental run products at $25^{\circ} \mathrm{C}(\mathbf{a}-\mathbf{d})$ and $100^{\circ} \mathrm{C}(\mathbf{e}-\mathbf{h})$. (a) Alteration of a plagioclase phenocryst top opaline silica at the rim of the experiment. (b) Strongly altered plagioclase core with intact rim next to pristine glass. (c) Preferential alteration of a specific growth zone in plagioclase with fluids access along fractures. (d) Alteration of plagioclase at experiment rim without any impact on clinopyroxene, titano-magnetite or glass. (e) Intense alteration of plagioclase core with rim partially intact. (f) Alteration of clinopyroxene to opaline silica along fractures with the matrix glass unaffected. (g) Alteration progressing into clinopyroxene from a fracture with glass in the matrix and present as inclusions unaffected. (h) Strongly altered plagioclase with disintegration of the altered core to a void. Abbreviations as in Figure 2. 
Plagioclase shows preferential alteration of An-rich compositional zones, with preservation of the most albitic growth zones (Figure 3b,c,e,h). In most cases, these An-rich zones are found in the core (e.g., Figure 3b), but where they are present at the rim, isolated preserved albitic zones can develop (Figure $3 \mathrm{~h}$ ). Cavities and a layered porous texture that traces original compositional zoning start to develop as plagioclase alteration progresses (Figure 4). Pyroxene is altered inward from fractures, partially guided by cleavage (Figure $3 \mathrm{f}, \mathrm{g}$ ) with no apparent compositional preference given that alteration cuts through concentric growth zoning. Moreover, alteration textures are identical for ortho- and clinopyroxene. The oxide phenocrysts show minimal alteration, especially at $25^{\circ} \mathrm{C}$. Where present, it consists of congruent dissolution along fractures. Glass is markedly unaffected. Boundaries between glass and fully altered plagioclase or pyroxene are razor sharp (Figure 3g,h and Figure 4) and represent the original boundary between the phenocryst and the matrix glass. Glass inclusions are also not affected and get exposed during alteration (Figure 3g). Rare veins of gypsum are observed as infill of altered plagioclase at $100{ }^{\circ} \mathrm{C}$ (Figure 4).

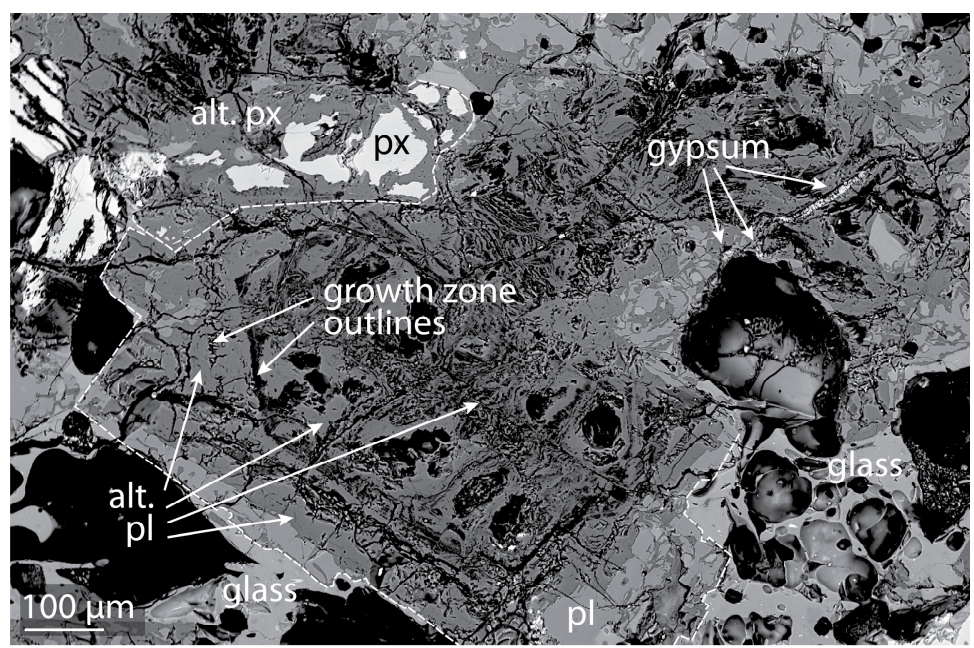

Figure 4. Back-scattered electron image of strongly altered area from the $100{ }^{\circ} \mathrm{C}$ experiment. Zoning in the original plagioclase is marked by changes in the texture of the opaline silica alteration product. The sodic rim of the plagioclase is preserved, whereas the core is altered and is starting to disintegrate. Pyroxene is similarly altered to opaline silica, but alteration does not follow growth zoning. Glass in the matrix and present as inclusions is preserved. Gypsum is present as vein infill in the altered plagioclase. Abbreviations as in Figure 2.

The compositions of minerals and glass in the starting andesite and their alteration products are given in Table 1. Compositions of visually unaffected minerals and glass in the run products are identical to those in the starting andesite. The fluid compositions are reported in Table 2. The fluids in both experiments have higher concentrations for most elements compared to the starting fluid with a larger difference for the $100^{\circ} \mathrm{C}$ experiment. 
Table 1. Mean major element compositions of the andesite phenocrysts and glass, and their alteration products as determined by WDS-EPMA. Atoms per formula unit (apfu) values normalised to the mineral cation sum, and to 1 for glass and the opaline silica alteration product. Values for $\mathrm{Fe}^{2+}$ and $\mathrm{Fe}^{3+}$ are calculated from the difference between cation and anion sums, and $\mathrm{X}_{\mathrm{Mg}}$ only includes $\mathrm{Fe}^{2+}$. Abbreviations used are $\mathrm{pl}$-plagioclase; $\mathrm{cpx}$ —clinopyroxene; opx-orthopyroxene; ox-oxide; alt—altered; n.a.—not analysed; n.d.—not determined.

\begin{tabular}{|c|c|c|c|c|c|c|c|}
\hline Mass \% & Glass & PL & CPX & Opx & Ox & Alt-P1 & Alt-Px \\
\hline $\mathrm{SiO}_{2}$ & 68.56 & 57.23 & 53.38 & 53.44 & 0.10 & 89.76 & 89.53 \\
\hline $\mathrm{TiO}_{2}$ & 0.55 & 0.06 & 0.26 & 0.24 & 12.64 & 0.05 & 0.25 \\
\hline $\mathrm{Al}_{2} \mathrm{O}_{3}$ & 14.71 & 26.45 & 0.83 & 0.69 & 2.86 & 0.51 & 0.05 \\
\hline $\mathrm{Cr}_{2} \mathrm{O}_{3}$ & 0.007 & n.a. & 0.008 & 0.006 & 0.031 & 0.000 & 0.009 \\
\hline $\mathrm{NiO}$ & 0.004 & n.a. & 0.01 & 0.01 & 0.02 & 0.01 & 0.01 \\
\hline $\mathrm{MgO}$ & 0.50 & 0.05 & 13.31 & 21.26 & 2.59 & 0.00 & 0.01 \\
\hline $\mathrm{MnO}$ & 0.08 & 0.02 & 0.61 & 0.96 & 0.56 & 0.01 & 0.01 \\
\hline $\mathrm{FeO}$ & 3.17 & 0.57 & 12.07 & 22.82 & 77.06 & 0.10 & 0.20 \\
\hline $\mathrm{CaO}$ & 1.79 & 9.13 & 20.78 & 1.63 & 0.03 & 0.03 & 0.04 \\
\hline $\mathrm{Na}_{2} \mathrm{O}$ & 3.96 & 5.66 & 0.33 & 0.04 & 0.03 & 0.05 & 0.10 \\
\hline $\mathrm{K}_{2} \mathrm{O}$ & 5.40 & 0.87 & 0.00 & 0.00 & 0.01 & 0.03 & 0.09 \\
\hline $\mathrm{P}_{2} \mathrm{O}_{5}$ & 0.11 & 0.02 & 0.01 & 0.01 & 0.00 & 0.00 & 0.02 \\
\hline $\mathrm{SO}_{3}$ & 0.01 & 0.01 & n.a. & 0.04 & n.a. & 0.72 & n.a. \\
\hline $\mathrm{F}$ & 0.14 & 0.03 & 0.01 & 0.00 & 0.01 & 0.07 & 0.03 \\
\hline $\mathrm{Cl}$ & 0.11 & n.a. & 0.01 & 0.01 & 0.00 & 0.27 & 0.38 \\
\hline Total & 99.10 & 100.10 & 101.61 & 101.18 & 95.94 & 91.61 & 90.73 \\
\hline \multicolumn{8}{|c|}{ Atoms per formula unit (apfu) } \\
\hline $\mathrm{Si}$ & 0.65 & 2.58 & 1.98 & 1.98 & 0.00 & 0.99 & 0.99 \\
\hline $\mathrm{Ti}$ & 0.00 & 0.00 & 0.01 & 0.01 & 0.35 & 0.00 & 0.00 \\
\hline $\mathrm{Al}$ & 0.16 & 1.41 & 0.04 & 0.03 & 0.12 & 0.01 & 0.00 \\
\hline $\mathrm{Cr}$ & 0.00 & 0.00 & 0.00 & 0.00 & 0.00 & 0.00 & 0.00 \\
\hline $\mathrm{Ni}$ & 0.00 & 0.00 & 0.00 & 0.00 & 0.00 & 0.00 & 0.00 \\
\hline $\mathrm{Mg}$ & 0.01 & 0.00 & 0.74 & 1.18 & 0.14 & 0.00 & 0.00 \\
\hline $\mathrm{Mn}$ & 0.00 & 0.00 & 0.02 & 0.03 & 0.02 & 0.00 & 0.00 \\
\hline $\mathrm{Fe}$ & 0.02 & 0.02 & 0.37 & 0.71 & 2.36 & 0.00 & 0.00 \\
\hline $\mathrm{Ca}$ & 0.02 & 0.44 & 0.83 & 0.06 & 0.00 & 0.00 & 0.00 \\
\hline $\mathrm{Na}$ & 0.07 & 0.50 & 0.02 & 0.00 & 0.00 & 0.00 & 0.00 \\
\hline K & 0.06 & 0.05 & 0.00 & 0.00 & 0.00 & 0.00 & 0.00 \\
\hline $\mathrm{P}$ & 0.00 & 0.00 & 0.00 & 0.00 & 0.00 & 0.00 & 0.00 \\
\hline$S$ & 0.00 & 0.00 & 0.00 & 0.00 & 0.00 & 0.01 & 0.00 \\
\hline $\mathrm{F}$ & 0.00 & 0.00 & 0.00 & 0.00 & 0.00 & 0.00 & 0.00 \\
\hline $\mathrm{Cl}$ & 0.00 & 0.00 & 0.00 & 0.00 & 0.00 & 0.01 & 0.01 \\
\hline $\mathrm{Fe}^{2+}$ & n.d. & n.d. & 0.36 & 0.71 & 1.19 & n.d. & n.d. \\
\hline $\mathrm{Fe}^{3+}$ & n.d. & n.d. & 0.02 & 0.00 & 1.17 & n.d. & n.d. \\
\hline $\mathrm{X}_{\mathrm{Mg}}$ & 0.22 & 0.13 & 0.67 & 0.62 & 0.11 & 0.00 & 0.10 \\
\hline
\end{tabular}


Table 2. Compositions of the starting and run product fluids as determined by ICP-OES and ICP-MS, the bulk composition of the starting andesite and the median composition of gypsum formed during Kawah Ijen quiescence (from [33]). Derived parameters include the enrichment factors of the experimental fluid, andesite and gypsum relative to the starting solution, results of mass balance calculations for congruous and incongruous andesite dissolution, and the calculated alteration mass flux (see the text for details on how these are calculated). Mass balance values and enrichment factors deviating from the general trend are highlighted in bold. Data are given in $\mathrm{mg} \mathrm{kg}^{-1}$ (n.d.- not detected, n.a.- - not analysed, - means negative values).

\begin{tabular}{|c|c|c|c|c|c|c|c|c|c|c|c|c|c|c|c|}
\hline \multirow[b]{2}{*}{ ICP-OES } & \multicolumn{3}{|c|}{$\begin{array}{c}\text { Concentrations } \\
\left(\mathrm{mg} \mathrm{kg}^{-1}\right)\end{array}$} & \multicolumn{2}{|c|}{ Enrichment Factor } & \multirow{2}{*}{$\begin{array}{c}\text { Andesite } \\
\left(\mathrm{mg} \mathrm{kg}^{-1}\right)\end{array}$} & \multirow{2}{*}{$\begin{array}{c}\text { Gypsum } \\
\left(\mathrm{mg} \mathrm{kg}^{-1}\right) \\
\text { average }\end{array}$} & \multirow{2}{*}{$\begin{array}{l}\text { Andesite } \\
\text { /KV15-002 }\end{array}$} & \multirow{2}{*}{$\begin{array}{l}\text { Gypsum } \\
\text { /KV15-002 }\end{array}$} & \multicolumn{2}{|c|}{$\begin{array}{c}\text { K mass Balance, } \\
\Delta \text { in } \%\end{array}$} & \multicolumn{2}{|c|}{$\begin{array}{l}\text { Incongruent Mass } \\
\text { Balance, } \Delta \text { in } \%\end{array}$} & \multicolumn{2}{|c|}{$\begin{array}{l}\text { Alteration Flux } \\
\left(\mathrm{mg} \mathrm{kg}^{-1} \text { day }^{-1}\right)\end{array}$} \\
\hline & KV15-002 & WRI-25C & WRI-100C & WRI-25C & WRI-100C & & & & & WRI-25C & WRI-100C & WRI-25C & WRI-100C & WRI-25C & WRI-100C \\
\hline $\mathrm{Si}$ & 37 & 72 & 85 & 1.9 & 2.3 & 273,395 & n.d. & 7366 & - & -97 & -954 & 42 & 10 & 24 & 33 \\
\hline $\mathrm{Ti}$ & 8 & 14 & 39 & 1.7 & 4.6 & 4375 & 2 & 519 & 0.3 & 30 & 43 & 37 & 65 & 4 & 21 \\
\hline $\mathrm{Al}$ & 5103 & 5356 & 6556 & 1.0 & 1.3 & 89,757 & 110 & 18 & 0.02 & 4 & 18 & 4 & 18 & 178 & 1020 \\
\hline $\mathrm{Mg}$ & 746 & 779 & 968 & 1.0 & 1.3 & 15,980 & 13 & 21 & 0.02 & 3 & 18 & 3 & 18 & 23 & 156 \\
\hline $\mathrm{Mn}$ & 43 & 45 & 56 & 1.0 & 1.3 & 1084 & 1 & 25 & 0.02 & 2 & 17 & 2 & 17 & 1 & 9 \\
\hline $\mathrm{Fe}$ & 2443 & 2554 & 3379 & 1.0 & 1.4 & 56,514 & 285 & 23 & 0.1 & 3 & 22 & 4 & 24 & 78 & 657 \\
\hline $\mathrm{Ca}$ & 798 & 774 & 811 & 1.0 & 1.0 & 42,453 & 232,800 & 53 & 292 & -5 & -15 & -5 & -15 & -17 & 9 \\
\hline $\mathrm{Na}$ & 809 & 805 & 898 & 1.0 & 1.1 & 26,113 & 102 & 32 & 0.1 & -2 & 1 & -2 & 1 & -3 & 63 \\
\hline $\mathrm{K}$ & 1248 & 1257 & 1323 & 1.0 & 1.1 & 24,074 & 51 & 19 & 0.04 & 0 & 0 & 0 & 2 & 6 & 53 \\
\hline $\mathrm{S}$ & 22,612 & 22,332 & 21,955 & 1.0 & 1.0 & 300 & 186,200 & 0.01 & 8 & -1 & -3 & -1 & -3 & -196 & -461 \\
\hline \multicolumn{16}{|l|}{ ICP-MS } \\
\hline $\mathrm{Li}$ & 12.9 & 12.9 & 14.2 & 1.0 & 1.1 & n.a. & 0.1 & - & 0.01 & - & - & 1 & 9 & 0.1 & 1.0 \\
\hline $\mathrm{Be}$ & 0.062 & 0.062 & 0.066 & 1.0 & 1.1 & 3.00 & n.d. & 48 & - & -1 & -9 & 0 & -1 & 0 & 0.003 \\
\hline $\mathrm{Sc}$ & 1.26 & 1.30 & 1.46 & 1.0 & 1.2 & 17 & 0.9 & 13 & 0.7 & 2 & 10 & 2 & 11 & 0.02 & 0.14 \\
\hline $\mathrm{V}$ & 14.8 & 14.8 & 20.6 & 1.0 & 1.4 & 153 & 0.1 & 10 & 0.01 & 0 & 26 & 0 & 27 & 0.01 & 4.1 \\
\hline $\mathrm{Cr}$ & 0.643 & 0.661 & 0.770 & 1.0 & 1.2 & 10 & 0.3 & 16 & 0.4 & 2 & 12 & 2 & 15 & 0.012 & 0.089 \\
\hline Co & 0.718 & 0.818 & 1.043 & 1.1 & 1.5 & 19 & 0.1 & 26 & 0.2 & 11 & 26 & 12 & 27 & 0.070 & 0.228 \\
\hline $\mathrm{Ni}$ & 0.282 & 0.291 & 0.316 & 1.0 & 1.1 & 5.6 & 1 & 20 & 5 & 3 & 5 & 3 & 5 & 0.007 & 0.024 \\
\hline $\mathrm{Cu}$ & 0.8 & 6.8 & 5.8 & 8.7 & 7.5 & 48 & 0.5 & 61 & 0.6 & 88 & 84 & 88 & 84 & 4.2 & 3.5 \\
\hline $\mathrm{Zn}$ & 6.37 & 6.48 & 6.94 & 1.0 & 1.1 & 29 & 4 & 5 & 0.7 & 2 & 7 & 1 & 5 & 0.08 & 0.40 \\
\hline $\mathrm{Ga}$ & 1.48 & 1.51 & 1.81 & 1.0 & 1.2 & 17 & 0.6 & 12 & 0.4 & 2 & 15 & 2 & 15 & 0.02 & 0.23 \\
\hline $\mathrm{Ge}$ & 0.061 & 0.061 & 0.061 & 1.0 & 1.0 & n.a. & 0.3 & - & 5 & - & - & - & - & 0 & 0 \\
\hline As & 3.49 & 3.46 & 3.19 & 1.0 & 0.9 & 0.9 & 0.3 & 0.3 & 0.1 & -1 & -9 & -1 & -10 & -0.02 & -0.21 \\
\hline $\mathrm{Se}$ & 0.06 & 0.07 & 0.08 & 1.3 & 1.4 & $<0.5$ & 0.5 & 4 & 8 & - & - & - & - & 0.01 & 0.01 \\
\hline $\mathrm{Rb}$ & 5.6 & 5.6 & 5.6 & 1.0 & 1.0 & 82 & 0.2 & 15 & 0.03 & -1 & -5 & -1 & -4 & -0.02 & -0.03 \\
\hline $\mathrm{Sr}$ & 20.9 & 20.9 & 24.6 & 1.0 & 1.2 & 407 & 664 & 19 & 32 & -1 & 10 & -1 & 11 & 0 & 2.6 \\
\hline Y & 1.03 & 1.08 & 1.12 & 1.0 & 1.1 & 28 & 3 & 27 & 3 & 3 & 0 & 3 & 0 & 0.03 & 0.06 \\
\hline $\mathrm{Zr}$ & 2.43 & 2.48 & 2.37 & 1.0 & 1.0 & 197 & 0.2 & 81 & 0.1 & -1 & -29 & 1 & -9 & 0.03 & -0.05 \\
\hline $\mathrm{Ag}$ & 0.006 & 0.006 & 0.006 & 1.0 & 1.0 & $<0.1$ & 0.01 & 9 & 2 & 2 & -2 & - & - & 0 & 0 \\
\hline $\mathrm{Cd}$ & 0.059 & 0.060 & 0.060 & 1.0 & 1.0 & $<0.1$ & 0.01 & 0.9 & 0.1 & 3 & -1 & - & - & 0.001 & 0.001 \\
\hline In & 0.037 & 0.041 & 0.040 & 1.1 & 1.1 & n.a. & 0.002 & - & 0.1 & - & - & - & - & 0.003 & 0.002 \\
\hline Cs & 0.06 & 0.06 & 0.06 & 1.0 & 1.0 & 3.3 & 0.1 & 51 & 1 & -2 & -16 & -1 & -12 & 0 & 0 \\
\hline $\mathrm{Ba}$ & $<0.2$ & $<0.2$ & $<0.4$ & & - & 620 & 76 & - & - & negative & negative & negative & negative & negative & negative \\
\hline $\mathrm{La}$ & 0.75 & 0.77 & 0.69 & 1.0 & 0.9 & 22.4 & 8 & 30 & 11 & 2 & -18 & 3 & -13 & 0.02 & -0.04 \\
\hline $\mathrm{Ce}$ & 1.75 & 1.81 & 1.60 & 1.0 & 0.9 & 46.8 & 29 & 27 & 16 & 2 & -19 & 3 & -15 & 0.04 & -0.11 \\
\hline
\end{tabular}


Table 2. Cont

\begin{tabular}{|c|c|c|c|c|c|c|c|c|c|c|c|c|c|c|c|}
\hline \multirow[b]{2}{*}{ ICP-OES } & \multicolumn{3}{|c|}{$\begin{array}{l}\text { Concentrations } \\
\left(\mathrm{mg} \mathrm{kg}^{-1}\right)\end{array}$} & \multicolumn{2}{|c|}{ Enrichment Factor } & \multirow{2}{*}{$\begin{array}{c}\text { Andesite } \\
\left(\mathrm{mg} \mathrm{kg}^{-1}\right) \\
\mathrm{KV}^{2} 15-008\end{array}$} & \multirow{2}{*}{$\begin{array}{c}\text { Gypsum } \\
\left(\mathrm{mg} \mathrm{kg}^{-1}\right) \\
\text { average }\end{array}$} & \multirow{2}{*}{$\begin{array}{c}\text { Andesite } \\
\text { /KV15-002 }\end{array}$} & \multirow{2}{*}{$\begin{array}{l}\text { Gypsum } \\
\text { /KV15-002 }\end{array}$} & \multicolumn{2}{|c|}{$\begin{array}{c}\text { K mass Balance, } \\
\Delta \text { in } \%\end{array}$} & \multicolumn{2}{|c|}{$\begin{array}{c}\text { Incongruent Mass } \\
\text { Balance, } \Delta \text { in } \%\end{array}$} & \multicolumn{2}{|c|}{$\begin{array}{l}\text { Alteration Flux } \\
\left(\mathrm{mg} \mathrm{kg}^{-1} \text { day }^{-1}\right)\end{array}$} \\
\hline & KV15-002 & WRI-25C & WRI-100C & WRI-25C & WRI-100C & & & & & WRI-25C & WRI-100C & WRI-25C & WRI-100C & WRI-25C & WRI-100C \\
\hline $\operatorname{Pr}$ & 0.219 & 0.227 & 0.197 & 1.0 & 0.9 & 5.7 & 4 & 26 & 20 & 3 & -20 & 3 & -17 & 0.006 & -0.015 \\
\hline $\mathrm{Nd}$ & 0.897 & 0.930 & 0.831 & 1.0 & 0.9 & 23.5 & 18 & 26 & 20 & 3 & -17 & 3 & -14 & 0.023 & -0.046 \\
\hline $\mathrm{Sm}$ & 0.194 & 0.202 & 0.186 & 1.0 & 1.0 & 5.1 & 3 & 27 & 16 & 3 & -13 & 3 & -10 & 0.006 & -0.005 \\
\hline $\mathrm{Eu}$ & 0.048 & 0.049 & 0.050 & 1.0 & 1.0 & 1.23 & 0.7 & 26 & 15 & 1 & -5 & 1 & -5 & 0.001 & 0.001 \\
\hline $\mathrm{Gd}$ & 0.213 & 0.223 & 0.215 & 1.0 & 1.0 & 5.4 & 1.5 & 25 & 7 & 3 & -7 & 4 & -3 & 0.007 & 0.002 \\
\hline $\mathrm{Tb}$ & 0.032 & 0.034 & 0.033 & 1.0 & 1.0 & 0.73 & 0.2 & 23 & 5 & 4 & -3 & 4 & 0 & 0.001 & 0.001 \\
\hline Dy & 0.184 & 0.195 & 0.199 & 1.1 & 1.1 & 5.1 & 0.7 & 28 & 4 & 4 & -1 & 5 & 3 & 0.007 & 0.010 \\
\hline Ho & 0.038 & 0.040 & 0.042 & 1.1 & 1.1 & 0.92 & 0.1 & 24 & 3 & 4 & 1 & 4 & 3 & 0.001 & 0.002 \\
\hline $\mathrm{Er}$ & 0.109 & 0.113 & 0.117 & 1.0 & 1.1 & 2.8 & 0.2 & 26 & 2 & 3 & 0 & 3 & 3 & 0.003 & 0.006 \\
\hline $\mathrm{Yb}$ & 0.100 & 0.104 & 0.109 & 1.0 & 1.1 & 2.77 & 0.1 & 28 & 1 & 3 & 0 & 3 & 3 & 0.003 & 0.006 \\
\hline $\mathrm{Lu}$ & 0.016 & 0.017 & 0.018 & 1.0 & 1.1 & 0.45 & 0.01 & 28 & 0.8 & 3 & 0 & 3 & 4 & 0.0004 & 0.001 \\
\hline $\mathrm{Hf}$ & 0.025 & 0.025 & 0.024 & 1.0 & 1.0 & 5.20 & 0.01 & 211 & 0.5 & -5 & -74 & 1 & -18 & 0 & -0.001 \\
\hline $\mathrm{Ta}$ & 0.0011 & 0.0010 & 0.0009 & 0.9 & 0.9 & 0.50 & 0.001 & 466 & 0.5 & -30 & -188 & - & - & -0.0001 & -0.0001 \\
\hline W & 0.0010 & 0.0010 & 0.0012 & 1.0 & 1.2 & 1.40 & n.d. & 1404 & - & -48 & -334 & - & - & 0 & 0.0002 \\
\hline $\mathrm{Tl}$ & 0.81 & 0.82 & 0.81 & 1.0 & 1.0 & $<0.1$ & 0.1 & 0.06 & 0.1 & 1 & -1 & 1 & 0 & 0.01 & 0.002 \\
\hline $\mathrm{Pb}$ & 5.12 & 5.14 & 4.82 & 1.0 & 0.9 & 1.60 & 16 & 0.3 & 3 & 0 & -6 & -1 & -18 & 0.01 & -0.21 \\
\hline $\mathrm{Bi}$ & 0.61 & 0.62 & 0.61 & 1.0 & 1.0 & $<0.1$ & 0.3 & 0.08 & 0.6 & 2 & -2 & - & - & 0.01 & 0.001 \\
\hline Th & 0.275 & 0.282 & 0.274 & 1.0 & 1.0 & 9 & 0.2 & 32 & 0.8 & 1 & -10 & 1 & -10 & 0.005 & -0.001 \\
\hline $\mathrm{U}$ & 0.058 & 0.059 & 0.060 & 1.0 & 1.0 & 2.6 & 0.003 & 44 & 0.05 & 0 & -11 & 0 & -10 & 0.001 & 0.001 \\
\hline
\end{tabular}




\section{Discussion}

\subsection{Alteration Textures}

The alteration textures observed in the experimental run products are nearly identical to those observed for naturally altered scoria samples from the Banyu Pahit riverbed (Figure 2d-f and [11,32]). In these, plagioclase alteration also commences in the An-rich zones and leaves glass inclusions and matrix glass untouched (Figure 2d,e, see also Figure 5 in [11]). Pyroxene alteration shows the same lack of compositional control, and alteration inward from fractures (Figure $2 f$, and [11,32]). The naturally altered samples commonly show a layered texture to the silica alteration product, which is less pronounced in the experiments. Given the lack of compositional differences between these layers [11], these may indicate intermittent fluid access for the natural samples. Lack of exsolution lamellae in the oxide phenocrysts of the scoria starting material likely explains the absence of preferential leaching of magnetite-rich domains observed previously [32]. The alteration sequence in both the natural and experimental scoria samples is anorthite-rich plagioclase $>$ pyroxene $>$ albite-rich plagioclase $>$ titano-magnetite $>$ glass, in agreement with observations at other volcanoes [33,34]. This order differs from that suggested by van Hinsberg et al. (2010) for a Kawah Ijen lava flow, where glass was concluded to have altered first [32]. However, the matrix glass was largely devitrified in that lava, suggesting that the alteration rock sequence studied by [32] did not provide information on the relative reactivity of glass.

\subsection{Compositional Changes}

The alteration product of plagioclase and pyroxene is dominantly composed of $\mathrm{SiO}_{2}$, although low totals indicate significant $\mathrm{H}_{2} \mathrm{O}$ (up to $8 \mathrm{wt} \%$, Table 1). This $\mathrm{H}_{2} \mathrm{O}$ content is markedly lower than the up to $20 \mathrm{wt} \%$ measured in opaline silica from naturally altered 1817 pumice by Lowenstern et al. (2018) [11]. Sulphur, chlorine and fluorine are also enriched in the alteration product compared to igneous minerals and glass. A similar S, Cl, and F enrichment was observed by Getahun et al. (1996) for altered plagioclase and pyroxene at Augustine Volcano [5]. No intermediate compositions between original mineral and alteration product are observed, nor progressive leaching away from the contact within the spatial resolution of the EPMA, similar to earlier findings [11,32]. However, there are consistent compositional differences between the silica alteration products formed after plagioclase and after pyroxene, with the former relatively enriched in Al, whereas the latter has higher Ti and Fe (Table 1).

The 25 and $100{ }^{\circ} \mathrm{C}$ run product fluids both have higher element concentrations than the starting solution (Table 2), and the $\mathrm{pH}$ has increased from 0.2 to 0.8 and 1.7, respectively. However, the increase in element abundance is not uniform as shown by the enrichment factor relative to the starting solution (Table 2, Figure 5a). The median enrichment factors are 1.03 and 1.07 for the 25 and $100{ }^{\circ} \mathrm{C}$ experiments, respectively, with a stronger enrichment in $\mathrm{Si}, \mathrm{Ti}, \mathrm{Co}, \mathrm{Se}$, and $\mathrm{Cu}$, and relative depletion in $\mathrm{Ta}$, the $\mathrm{LREE}$, As and $\mathrm{Pb}$. This suggests preferential leaching of the former, and precipitation of the latter. However, the magnitude and direction of the change in fluid composition also depends on whether a given element is more abundant in the rock, or in the fluid the rock is interacting with. In the case of our experiments, this effect is not as pronounced as might be expected given that the lake derives its cation composition predominantly from alteration of igneous rocks of similar composition to the andesite used here [18,21]. As a result, many of the elements are present at a constant ratio between andesite and fluid (Table 2, Figure 5b), which represents the apparent water-rock ratio of the lake water [18]. The majority of elements are higher in the andesite than in the lake water, in particular $\mathrm{Si}, \mathrm{Ti}, \mathrm{Zr}, \mathrm{Hf}, \mathrm{Ta}$ and $\mathrm{W}$. In contrast, $\mathrm{S}, \mathrm{As}, \mathrm{Tl}, \mathrm{Bi}$, and $\mathrm{Pb}$ are higher in the lake water, in agreement with these elements being derived not from rock leaching, but from magmatic gases entering the lake [21,35]. 

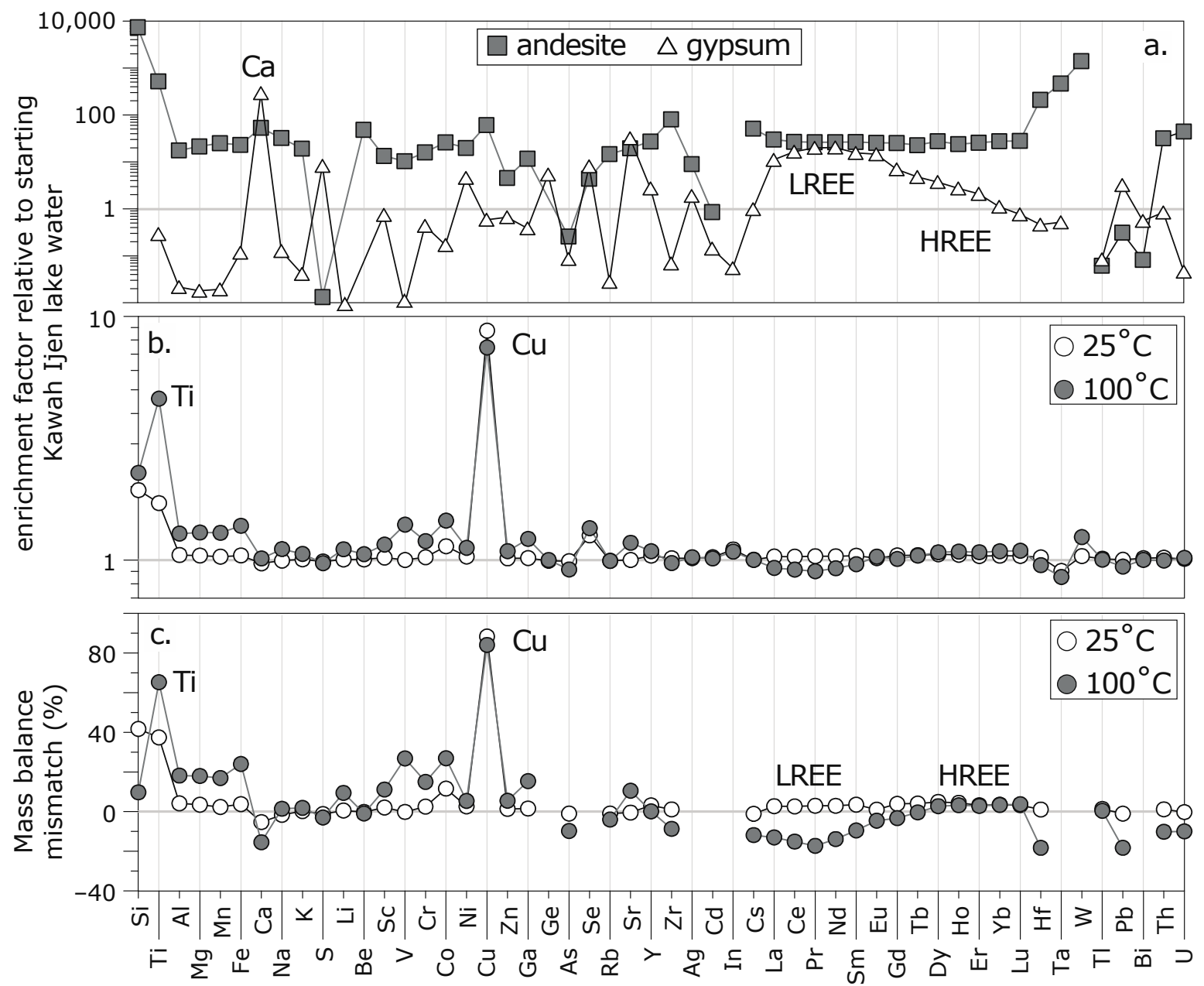

Figure 5. Enrichment factors for (a) andesite, gypsum and (b) the run product fluids relative to the starting solution, and (c) the \% mismatch in composition for a mass balance calculation assuming incongruous andesite dissolution (see text for details on mass balance calculation).

To account for the andesite element abundances, we have calculated the deviation in composition between that measured and that predicted assuming congruent dissolution of the rock in an amount calculated relative to mass balance for the element $\mathrm{K}$ (Table 2). This makes the explicit assumption that $\mathrm{K}$ is conservative and is not a significant component of any precipitated phases. The calculation shows relative enrichments for $\mathrm{Ti}, \mathrm{Co}$, and $\mathrm{Cu}$ compared to congruent dissolution, and depletions in the LREE, Ta and W. Silica is strongly depleted. The strong depletion in Si results from the alteration being incongruent, leaving behind an opaline silica alteration product [11,14,20]. An incongruent dissolution element flux has been calculated for Banyu Pahit riverbed alteration of andesite lava [14], based on an in-situ alteration sequence. When this is used instead, the Si depletion decreases strongly and a better overall agreement is obtained (Table 2, Figure $5 \mathrm{c}$ ). The $25^{\circ} \mathrm{C}$ experiment largely shows the same pattern as the $100{ }^{\circ} \mathrm{C}$ run, but with less amplitude, suggesting that there are no significant differences in alteration processes between these temperatures.

The element pattern in Figure $5 \mathrm{c}$ agrees with textural observations of the alteration. Preferential alteration of An-rich plagioclase and pyroxene over albite-rich (Ab-rich) plagioclase and glass leads to stronger leaching of $\mathrm{Al}, \mathrm{Mg}, \mathrm{Mn}$, and $\mathrm{Fe}$ than $\mathrm{Na}$ and $\mathrm{K}$. The increase in Ti is unexpected because titano-magnetite appeared only minimally affected by alteration. Pyroxene is also an important Ti host (up to $1550 \mathrm{ppm}$, Table 1), but as will be shown below, its alteration alone cannot explain the Ti. Both Ca and $\mathrm{S}$ show a significant relative depletion, in agreement with the gypsum precipitates observed in the experiments. The decrease is not at a molar Ca:S ratio of 1, because $\mathrm{Ca}$ is also leached from plagioclase 
and clinopyroxene, and $S$ is enriched in the silica alteration product. Gypsum formed from the seepage waters at Kawah Ijen is relatively enriched in the LREE compared to its formation waters [21,36], and gypsum precipitation is therefore also the likely explanation for their relative depletion.

\subsection{Alteration Flux}

The changes in water composition for these known-duration experiments allow for alteration fluxes to be calculated. These are time-integrated values whereas the fluxes and rates will likely have varied as the experiment, and the alteration progressed (see also [14,37]). The calculated alteration fluxes are given in Table 2 in units of mg element released per $\mathrm{kg}$ starting andesite per day. The calculation of the flux per $\mathrm{kg}$ of andesite assumes that the rock is the limiting factor in the alteration element release, chosen here because alteration has not reached completion in either experiment. This is, moreover, also the case for natural alteration in the Banyu Pahit river valley where the high flow rates will hinder attainment of equilibrium between rock and fluid. Most elements are released into the fluid, except for $\mathrm{Si}, \mathrm{Ca}, \mathrm{S}, \mathrm{As}, \mathrm{Zr}, \mathrm{Hf}, \mathrm{Th}, \mathrm{Ta}, \mathrm{Ba}, \mathrm{Pb}$ and the LREE that are sequestered into alteration product phases $\mathrm{Na}$ and $\mathrm{Rb}$ differences are within their uncertainty). The depletion of $\mathrm{Ca}, \mathrm{S}$ and the LREE is in agreement with gypsum precipitation and silica with the abundant opal, but a host for the other elements with negative fluxes was not observed. Mineral saturation indices calculated for the run product solutions with PHREEQC 2.17 and the Lawrence Livermore National Laboratory database [38] suggest that $\mathrm{Zr}$, $\mathrm{Ti}$, Ba and Si should precipitate, with multiple minerals, including barite, zircon, baddeleyite, rutile, anatase, amorphous silica and cristobalite at saturation. Gypsum is predicted to be just undersaturated $(\mathrm{S} . \mathrm{I} .=-0.13)$. Barite precipitates at Kawah Ijen are known to be high in $\mathrm{Pb}$ [32] and $\mathrm{Hf}$ and Th would likely be incorporated into a $\mathrm{Zr}$-phase given their similarity in size and/or charge. Only $1.5 \mu \mathrm{g}$ of $\mathrm{ZrO}_{2}$ would be required to explain the change in $\mathrm{Zr}$ concentration, making it near impossible to detect in the alteration run product, and precipitation of a $Z r$-phase would thus be a viable explanation for the Zr behaviour.

The flux values are three orders of magnitude lower than those calculated for lava flow alteration in the Banyu Pahit riverbed by van Hinsberg et al. (2010) [14], even for the higher flux at $100{ }^{\circ} \mathrm{C}$ (Figure 6). This lower reactivity likely reflects the glass component of the scoria being resistant to alteration and therefore not contributing to the element flux. As will be shown below, glass makes up approximately $50 \mathrm{wt} \%$ of the scoria and its persistence will therefore have a significant impact on the element release. Contrary to what might be expected from its much larger exposed surface area, andesite scoria therefore alters at a slower rate than the crystalline andesite lava flow that makes up the Banyu Pahit riverbed. As discussed by [14], the Banyu Pahit element load increases downstream from the springs, when corrected for groundwater dilution, as a result of water-rock interaction (i.e., elements continue to be leached from the riverbed, but overall element concentrations decrease owing to dilution by groundwater). Using the flux values calculated from the $25{ }^{\circ} \mathrm{C}$ experiment, approximately $4 \mathrm{~m}$ of scoria would need to be altered per day per meter of river along the upstream river valley to account for the observed change in river water element flux. This does not match field topography. Less material is required when the lava alteration rate is used. The change in water composition also matches the lava element flux better, especially for $\mathrm{Cu}, \mathrm{Co}$ and $\mathrm{K}$ (Figure 6), supporting that alteration of the 1817 scoria is not a strong contributor. However, as shown by [14], the observed river incision in the lava flow is still not sufficient to account for the alteration flux recorded by the river water and an additional influx of material is required. The upper Banyu Pahit valley has steep sides (Figure 1a) that expose a series of thin lava flows alternating with lahar and mudflows, and a poorly welded pyroclastic flow, and there is abundant evidence of rockslides and falls from these valley sides that would contribute material to the valley and the river. 


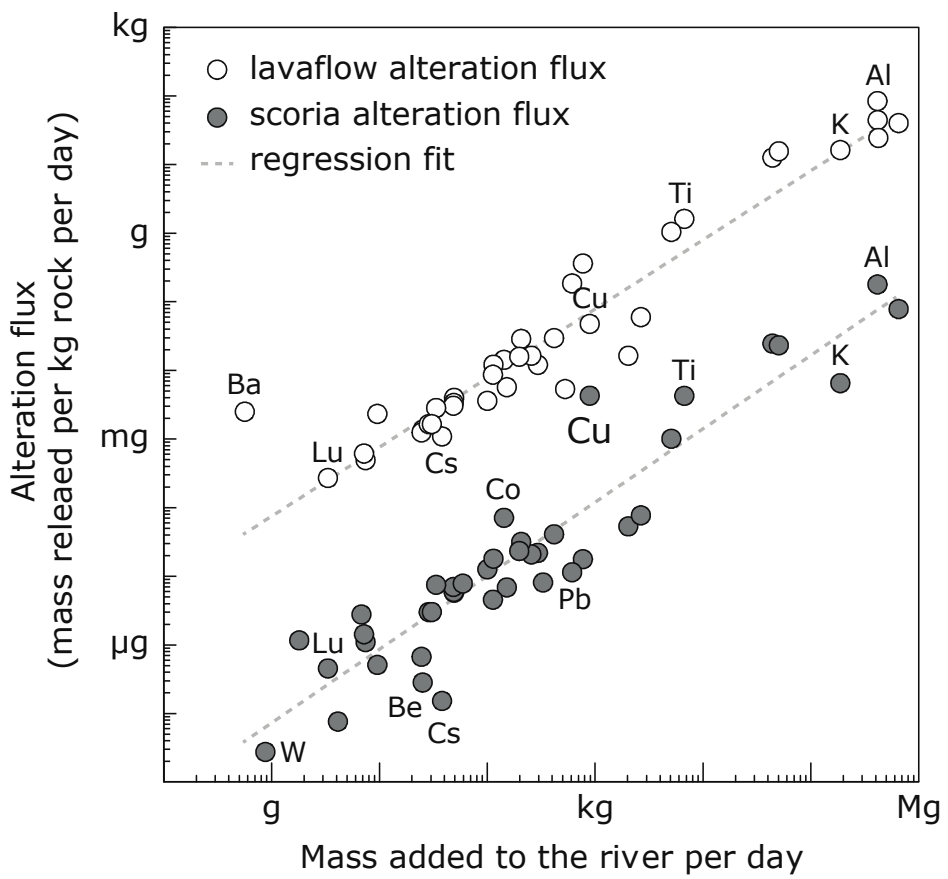

Figure 6. Change in upstream Banyu Pahit river water composition, corrected for dilution, compared to the alteration flux calculated from the experiments and from naturally altered Kawah Ijen andesitic lava.

\subsection{Alteration Mass Balance}

The experiments were run under closed-system conditions and changes in fluid chemistry must therefore be balanced by alteration of the andesite phases and by mineral precipitation. The contributions of each phase and the amount of precipitation can be calculated by mass balance when the compositions of the phases are known.

The trace element compositions of the minerals and glass were estimated by solving for mass balance whilst relative concentrations $(C)$ among the phases were fixed by their element distribution coefficients $(D)$ :

$$
\begin{aligned}
& D_{i}^{\text {mineral } / \text { melt }}=\frac{C_{i}^{\text {mineral }}}{C_{i}^{\text {melt }}} \\
& C_{i}^{\text {mineral }}=D_{i}^{\text {mineral } / \text { melt }} \cdot C_{i}^{\text {melt }} \\
& C_{i}^{\text {melt }}=\frac{C_{i}^{\text {bulk }}}{\left\{C_{i}^{\text {melt }} \cdot\left(X_{c p x} \cdot D_{i}^{c p x}+X_{o x} \cdot D_{i}^{o x}+X_{A n 40} \cdot D_{i}^{A n 40}+X_{A n 60} \cdot D_{i}^{A n 60}+X_{m e l t}\right)\right\}}
\end{aligned}
$$

The modes $\left(X_{i}\right)$ were calculated from least squares multiple linear regression on the mean major element compositions of the phases as determined by EPMA (Table 1$)$. The calculated mode is $49 \%$ glass, $5 \%$ clinopyroxene, $8 \%$ orthopyroxene, $4 \%$ oxide, $1.4 \% A n_{40}$ and $32 \% A n_{60}$ plagioclase (mean relative deviation in predicted bulk composition is $2.8 \%$ ). The plagioclase compositions represent the 1st and 3rd quartile of the plagioclase analyses. The calculated modes appear reasonable when compared to images of the starting material (e.g., Figure 2a). Partition coefficients for clino- and orthopyroxene and $A n_{40}$ and $A n_{60}$ plagioclase were determined using the systematics in element partitioning given in [39-42], using a temperature of $950{ }^{\circ} \mathrm{C}$ and $3 \mathrm{wt} \% \mathrm{H}_{2} \mathrm{O}$ in the melt as calculated from feldspar-melt thermometry and hygrometry [43]. Titano-magnetite $D$-values are from [44]. Estimated mineral and melt compositions are given in Table 3. Not all $D$-values can be extrapolated to the temperature and melt composition of our andesite sample, and the results are therefore only approximate, although the relative abundances among the phases agree with those measured for phenocrysts in a Kawah Ijen andesite lava [32]. 
Table 3. Estimated modes and trace element concentrations for phenocrysts and glass in the andesite starting material. Abbreviations as in Table 1, $A n_{40}$ and $A n_{60}$ are plagioclase at 40 and 60 mole \% anorthite component respectively.

\begin{tabular}{|c|c|c|c|c|c|c|}
\hline Phase & Glass & Cpx & Opx & Oxide & $\mathrm{An}_{40}$ & $\mathrm{An}_{60}$ \\
\hline $\begin{array}{r}\text { mode (mass \%) } \\
\text { Concentrations (mg }\end{array}$ & 49 & 5 & 8 & 4 & 1.4 & 32 \\
\hline Sc & 12 & 171 & 17 & 18 & 6 & 2 \\
\hline $\mathrm{V}$ & 90 & 90 & 67 & 2434 & 4 & 2 \\
\hline $\mathrm{Cr}$ & 3 & 2 & 21 & 179 & 0.2 & 0.1 \\
\hline Co & 8 & 13 & 141 & 64 & 2 & 2 \\
\hline $\mathrm{Ni}$ & 2 & 13 & 16 & 65 & 0.11 & 0.03 \\
\hline $\mathrm{Cu}$ & 62 & 61 & 3 & 48 & 37 & 37 \\
\hline $\mathrm{Zn}$ & 17 & 62 & 143 & 138 & 5 & 2 \\
\hline $\mathrm{Ga}$ & 14 & 4 & 4 & 41 & 21 & 24 \\
\hline $\mathrm{Rb}$ & 161 & 2 & 8 & 0.2 & 8 & 6 \\
\hline $\mathrm{Sr}$ & 319 & 10 & 15 & 7 & 1218 & 717 \\
\hline $\mathrm{Y}$ & 53 & 32 & 3 & 1 & 0.7 & 1 \\
\hline $\mathrm{Zr}$ & 387 & 48 & 12 & 76 & 4 & 2 \\
\hline Sn & 8 & 4 & 2 & 7 & 1 & 1 \\
\hline Cs & 6 & 0.02 & 0.3 & 0.01 & 0.6 & 0.5 \\
\hline $\mathrm{Ba}$ & 1006 & 6 & 47 & 1 & 716 & 348 \\
\hline $\mathrm{La}$ & 41 & 1 & 0.01 & 0.03 & 10 & 7 \\
\hline $\mathrm{Ce}$ & 86 & 6 & 0.07 & 0.2 & 18 & 13 \\
\hline $\operatorname{Pr}$ & 11 & 1 & 0.02 & 0.04 & 2 & 1 \\
\hline $\mathrm{Nd}$ & 44 & 6 & 0.1 & 0.2 & 5 & 5 \\
\hline $\mathrm{Sm}$ & 10 & 3 & 0.1 & 0.1 & 0.6 & 0.6 \\
\hline $\mathrm{Eu}$ & 2 & 0.8 & 1.7 & 0.04 & 0.1 & 0.1 \\
\hline $\mathrm{Gd}$ & 10 & 5 & 0.2 & 0.3 & 0.4 & 0.4 \\
\hline $\mathrm{Tb}$ & 1 & 0.8 & 0.05 & 0.05 & 0.03 & 0.04 \\
\hline Dy & 9 & 6 & 0.5 & 0.5 & 0.2 & 0.2 \\
\hline Ho & 2 & 1 & 0.1 & 0.1 & 0.02 & 0.03 \\
\hline Er & 5 & 4 & 0.5 & 0.5 & 0.05 & 0.07 \\
\hline $\mathrm{Yb}$ & 5 & 4 & 0.8 & 0.8 & 0.03 & 0.04 \\
\hline $\mathrm{Lu}$ & 0.8 & 0.6 & 0.1 & 0.1 & 0.003 & 0.006 \\
\hline $\mathrm{Hf}$ & 10 & 2 & 2 & 2 & 0.2 & 0.2 \\
\hline $\mathrm{Pb}$ & 2 & 0.05 & 0.1 & 3 & 2 & 1 \\
\hline Th & 16 & 2 & 2 & 0.2 & 0.2 & 2 \\
\hline $\mathrm{U}$ & 5 & 0.2 & 0.5 & 0.1 & 0.5 & 0.2 \\
\hline
\end{tabular}

The relative contributions of the andesite phases and of gypsum precipitation to the changes in fluid composition were calculated using non-negative least squares (NNLS) multiple linear regression [45]. This type of regression does not allow for negative regression coefficients, and therefore avoids negative mineral dissolution, which would be meaningless for alteration modelling. However, mineral precipitation is a valid negative contribution, and gypsum concentrations were therefore included as negative values to allow for gypsum precipitation in NNLS. This approach assumes congruent dissolution of the minerals, which does not represent reality, especially for Si. Unfortunately, the trace element composition of the silica alteration product is not known and cannot be estimated for lack of silica-fluid partition coefficients. Only its major element composition was therefore included. To account for the lack of trace element data for the silica alteration product, as well as the estimated nature of these data for the andesite phases, the major elements were given a relative weight of 10 compared to the trace elements in the NNLS regression. The elements that are predicted to go into precipitated phases $(\mathrm{Zr}, \mathrm{Hf}, \mathrm{Ba}, \mathrm{Ti})$ are poorly reproduced in the NNLS regression, as they should be, and were excluded.

The mass-balance approach predicts no contributions from glass, orthopyroxene or $A n_{40}$ at $25^{\circ} \mathrm{C}, 8 \mathrm{mg}$ of gypsum precipitation and dissolution of $10 \mathrm{mg}$ of $A n_{60}, 5 \mathrm{mg}$ of clinopyroxene and 
$1 \mathrm{mg}$ of magnetite. This agrees with the preservation of glass, but no gypsum precipitates were observed, although they could have been overlooked at this small amount. The $\mathrm{Cu}$ concentration is not reproduced and is a factor of 9 too high, suggesting that $\mathrm{Cu}$ has a different source. There is also an overall small enrichment in the elements compared to the starting solution. This enrichment does not appear to be linked to a specific phase, given that the REE pattern is parallel to that of the starting solution. We rather attribute it to extraction of water from the fluid by hydration resulting in concentrating the solution, although the loss of vapour condensate will also have an impact (see the Results section). The effect of fluid concentration by rock hydration is likely to take place in the natural setting as well, and will in fact be more pronounced given that the natural opaline silica has up to $20 \mathrm{wt} \%$ water [11]. As shown by Lowenstern et al. (2018) [11], part of this water is present as $\mathrm{OH}$, and the formation of opaline silica will thus also increase the $\mathrm{pH}$ of the fluid.

Gypsum precipitation is predicted at $100{ }^{\circ} \mathrm{C}(114 \mathrm{mg})$, together with dissolution of $58 \mathrm{mg}$ of $\mathrm{An}_{60}, 12 \mathrm{mg}$ of clinopyroxene, $15 \mathrm{mg}$ of orthopyroxene and $16 \mathrm{mg}$ of magnetite. Glass and $\mathrm{An}_{40}$ are predicted not to contribute to the fluid. This agrees with the gypsum precipitates that are present and observations in the altered rock fragment where glass is preserved, plagioclase is altered more than pyroxene and there is a strong preferential alteration of more An-rich plagioclase zones (Figure 3). It also fits the more extensive interaction observed at $100{ }^{\circ} \mathrm{C}$ compared to $25{ }^{\circ} \mathrm{C}$. Magnetite dissolution is required to satisfy the change in Fe-content, but overestimates the change in Ti. This could reflect incongruent magnetite dissolution as has been documented for altered rocks in the Banyu Pahit riverbed [32]. However, this texture was not observed in the experimental run products, where oxide alteration appears to be congruous along fractures (Figure 3). Titanium precipitation may subsequently take place elsewhere, because $\mathrm{Ti}$ is predicted to be at rutile and anatase saturation. Similar to the $25^{\circ} \mathrm{C}$ experiment, $\mathrm{Cu}$ is not reproduced. Moreover, $\mathrm{Zr}, \mathrm{Hf}, \mathrm{Ta}$, and $\mathrm{Ba}$ are strongly retained in the altered rock, which agrees with the predicted saturation indices of a $\mathrm{Zr}$-mineral and barite. The measured changes in the fluid $\mathrm{Ca}$ and $\mathrm{Na}$ contents deviate from that predicted, which probably reflects the inclusion of two discrete plagioclase compositions rather than a continuous series.

The strong release of $\mathrm{Cu}$ to the fluid cannot be explained by dissolution of the phenocrysts and indicates involvement of an additional phase. $\mathrm{Cu}-\mathrm{Fe}$-sulphide has been observed as spherical inclusions in magnetite phenocrysts and in the matrix glass (Figure 7), where it appears to represent an immiscible sulphide liquid (see also [35]). Sulphides are calculated to be unstable in the Kawah Ijen lake water (saturation index of chalcopyrite is -109), and the saturation index is predicted to decrease even further for the experiments, where the $\mathrm{fO}_{2}$ of the fluid further increases as it interacts with $\mathrm{O}_{2}$ from air in the headspace of the reaction vessel. To explain the increase in $\mathrm{Cu}, 0.25 \mathrm{mg}$ of sulphide would need to be dissolved, which would represent a mode of $0.04 \%$, which is compatible with the observed amount of sulphide globules. The $\mathrm{Cu}$ enrichment is approximately equal in the 25 and $100{ }^{\circ} \mathrm{C}$ experiments, indicating that the sulphide globules were leached relatively fast and that their dissolution may have gone to completion. This suggests that the sulphide is the first phase to be affected by alteration thereby releasing a pulse of $\mathrm{Cu}$ to the fluid early in the alteration, despite it being hosted by the two most resistant phases of the rock; oxide and glass. Exposure to the fluid must therefore have been provided by fractures. Strong variations in $\mathrm{Cu}$ concentration have been observed in a three-year duration (2015-2018), biweekly sampled timeseries of Banyu Pahit river water composition [46], thereby indeed suggesting an important role for sulphides in controlling $\mathrm{Cu}$ concentrations during water-rock interaction at Kawah Ijen. 


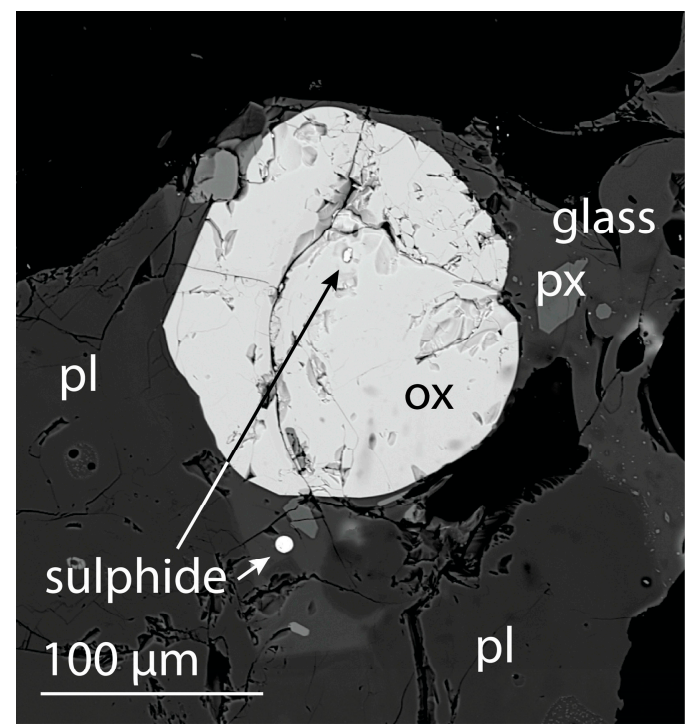

Figure 7. Back-scattered electron image of two spherical $\mathrm{Cu}-\mathrm{Fe}$-sulphide grains in the starting andesite, one enclosed in a titano-magnetite phenocryst, the other in matric glass.

\section{Conclusions}

The experimental interaction between andesite scoria and hyperacid lake waters from Kawah Ijen volcano reproduces the alteration textures observed from this water-rock interaction in the natural setting. The 25 and $100{ }^{\circ} \mathrm{C}$ experiments produce similar alteration products and textures, and differ mainly in the intensity of alteration. Silicates are altered to amorphous hydrous silica with a sub-micron transition from fresh to fully altered, and a preferential alteration of the calcic domains in plagioclase. Sulfides and oxides appear to dissolve congruently. Glass persists, giving an alteration sequence of $\mathrm{Cu}-\mathrm{Fe}$-sulphide $>$ calcic plagioclase $>$ pyroxene $>$ titano-magnetite $>$ sodic plagioclase $>$ glass. As a result, alteration preferentially releases $\mathrm{Cu}, \mathrm{Ca}, \mathrm{Al}, \mathrm{Mg}$, Fe and phenocryst-compatible trace elements, whereas $\mathrm{K}$ and the incompatible elements, which are enriched in glass, are retained. The release of Ca during alteration saturates the experimental fluid in gypsum, and gypsum precipitates are observed both as veins in the altered scoria fragment and as idiomorphic crystals in the fluid. The LREE preference of gypsum results in a strong LREE over HREE depletion in the final fluid.

The experimental alteration flux differs from that determined for the upstream Banyu Pahit river in both quantity and elemental signature. The experimental flux is significantly lower and the compatible over incompatible element enrichment resulting from preferential phenocryst alteration is not observed. Moreover, gypsum precipitation is less pronounced than would be predicted from the experiments. Gypsum is observed in the Banyu Pahit valley around the seepage springs, but is absent further downstream. This likely results from the groundwater dilution that accompanies alteration in the Banyu Pahit river, thereby avoiding gypsum saturation. The higher alteration flux and lack of incompatible element depletion suggest that quenched glassy scoria is but a minor contributor to the alteration flux in the Banyu Pahit river, and that fully crystalline lavas, notwithstanding their lower surface area, are the dominant altered rock type.

Author Contributions: The study was conceived by V.v.H., K.B. and J.L.; experiments and modelling were conducted by V.v.H. and samples analysed by V.v.H. and K.B. All authors contributed to data interpretation, figure preparation and writing of the paper. All authors have read and agreed to the published version of the manuscript.

Funding: This research was funded by an Osisko Research stipend to V.H., and NSERC Discovery Grant funding to K.B., with fieldwork financially supported by the Volcano Disaster Assistance Program of USAID and the USGS. 
Acknowledgments: We thank Corentin Caudron, Maria Martínez-Cruz, John Pallister, Dmitri Rouwet, Heather Wright, Peter Kelly and the other participants of the Cities on Volcanoes 8 Wet Volcanoes workshop for discussions on the Kawah Ijen system and a fruitful exchange of ideas. We also thank Pak Heri and Pak Parjan for help in the field, and we acknowledge the generous logistical support by CVGHM. Three reviewers provided insightful comments and suggestions that improved the final manuscript.

Conflicts of Interest: The authors declare no conflict of interest. Any use of trade, firm, or product names is for descriptive purposes only and does not imply endorsement by the U.S. Government.

\section{References}

1. Henley, R.W.; Berger, B.R. Nature's refineries-Metals and metalloids in arc volcanoes. Earth Sci. Rev. 2013, 125, 146-170. [CrossRef]

2. Hedenquist, J.W.; Lowenstern, J.B. The role of magmas in the formation of hydrothermal ore deposits. Nature 1994, 370, 519-527. [CrossRef]

3. Arribas, A.; Hedenquist, J.W.; ITAYA, T.; Okada, T.; Concepción, R.A.; Garcia, J.S. Contemporaneous formation of adjacent porphyry and epithermal $\mathrm{Cu}-\mathrm{Au}$ deposits over $300 \mathrm{ka}$ in northern Luzon, Philippines. Geology 1995, 23, 337-340. [CrossRef]

4. Spilde, M.; Brearley, A.; Papike, J. Alteration of plagioclase and pyroxene phenocrysts in a fissure fumarole, Valley of Ten Thousand Smokes, Alaska. Am. Mineral. 1993, 78, 1066-1081.

5. Getahun, A.; Reed, M.; Symonds, R. Mount St Augustine volcano fumarole wall rock alteration: Mineralogy, zoning, composition and numerical models of its formation process. J. Volcanol. Geotherm. Res. 1996, 71, 73-107. [CrossRef]

6. Sillitoe, R.H. Porphyry Copper Systems. Econ. Geol. 2010, 105, 3-41. [CrossRef]

7. Henley, R.W.; Berger, B.R. Magmatic-vapor expansion and the formation of high-sulfidation gold deposits: Chemical controls on alteration and mineralization. Ore Geol. Rev. 2011, 39, 63-74. [CrossRef]

8. King, J.; Williams-Jones, A.E.; van Hinsberg, V.; Williams-Jones, G. High-sulfidation epithermal pyrite-hosted $\mathrm{Au}(\mathrm{Ag}-\mathrm{Cu})$ ore formation by condensed magmatic vapors on Sangihe Island, Indonesia. Econ. Geol. 2014, 109, 1705-1733. [CrossRef]

9. Stoffregen, R. Genesis of acid-sulfate alteration and $\mathrm{Au}-\mathrm{Cu}-\mathrm{Ag}$ mineralization at Summitville, Colorado. Econ. Geol. 1987, 82, 1575-1591. [CrossRef]

10. Varekamp, J.C. The chemical composition and evolution of volcanic lakes. In Volcanic Lakes; Rouwet, D., Christenson, B., Tassi, F., Vandemeulebrouck, J., Eds.; Springer: Berlin/Heidelberg, Germany, 2015; pp. $93-123$.

11. Lowenstern, J.B.; van Hinsberg, V.; Berlo, K.; Liesegang, M.; Iacovino, K.; Bindeman, I.N.; Wright, H.M. Opal-A in glassy pumice, acid alteration, and the 1817 phreatomagmatic eruption at kawah ijen (Java), Indonesia. Front. Earth Sci. 2018, 6. [CrossRef]

12. Scher, S.; Williams-Jones, A.E.; Williams-Jones, G. Fumarolic activity, acid-sulfate alteration, and high sulfidation epithermal precious metal mineralization in the crater of Kawah Ijen volcano, Java, Indonesia. Econ. Geol. 2013, 108, 1099-1118. [CrossRef]

13. Caudron, C.; Syahbana, D.K.; Lecocq, T.; van Hinsberg, V.; McCausland, W.; Triantafyllou, A.; Camelbeeck, T.; Bernard, A. Surono Kawah Ijen volcanic activity: A review. Bull. Volcanol. 2015, 77, 16. [CrossRef]

14. van Hinsberg, V.; Berlo, K.; Sumarti, S.; van Bergen, M.; Williams-Jones, A. Extreme alteration by hyperacidic brines at Kawah Ijen volcano, East Java, Indonesia: II Metasomatic imprint and element fluxes. J. Volcanol. Geotherm. Res. 2010, 196, 169-184. [CrossRef]

15. Handley, H.K.; Macpherson, C.G.; Davidson, J.P.; Berlo, K.; Lowry, D. Constraining fluid and sediment contributions to subduction-related magmatism in Indonesia: Ijen Volcanic Complex. J. Petrol. 2007, 48, 1155-1183. [CrossRef]

16. Sitorus, K. Volcanic Stratigraphy and Geochemistry of the Idjen Caldera Complex, Indonesia. Master's Thesis, Victoria University of Wellington, Wellington, New Zealand, 1990; 148p.

17. Kemmerling, G.L.L. Het Idjen Hoogland. De Geologie en Geomorphologie van den Idjen; G. Kolff \& Co.: Batavia, Dutch East Indies, 1921; Volume II, 143p.

18. Delmelle, P.; Bernard, A. Geochemistry, mineralogy, and chemical modeling of the acid crater lake of Kawah Ijen Volcano, Indonesia. Geochim. Cosmochim. Acta 1994, 58, 2445-2460. [CrossRef]

19. Delmelle, P.; Bernard, A.; Kusakabe, M.; Fischer, T.P. Geochemistry of the magmatic-hydrothermal system of Kawah Ijen volcano, East Java, Indonesia. J. Volcanol. Geotherm. Res. 2000, 97, 31-53. [CrossRef] 
20. Takano, B.; Suzuki, K.; Sugimori, K.; Ohba, T.; Fazlullin, S.M.; Bernard, A.; Sumarti, S.; Sukhyar, R.; Hirabayashi, M. Bathymetric and geochemical investigation of Kawah Ijen crater lake, east Java, Indonesia. J. Volcanol. Geotherm. Res. 2004, 135, 299-329. [CrossRef]

21. van Hinsberg, V.; Vigouroux, N.; Palmer, S.; Berlo, K.; Mauri, G.; Williams-Jones, A.; McKenzie, J.M.; Williams-Jones, G.; Fischer, T.P. Element flux to the environment of the passively degassing crater lake-hosting Kawah Ijen volcano, Indonesia, and implications for estimates of the global volcanic flux. Geol. Soc. Lond. Spec. Publ. 2017, 437, 9-34. [CrossRef]

22. Woudstra, H. Analyse van Merkwaardige Watersoorten op het Idjen-Hoogland; G. Kolff \& Co.: Batavia, Dutch East Indies, 1921; Volume II, 17p.

23. Caudron, C.; Lecocq, T.; Syahbana, D.K.; McCausland, W.; Watlet, A.; Camelbeeck, T.; Bernard, A. Surono Stress and mass changes at a wet volcano: Example during the 2011-2012 volcanic unrest at Kawah Ijen volcano (Indonesia). J. Geophys. Res. Solid Earth 2015, 120, 5117-5134. [CrossRef]

24. Tonini, R.; Sandri, L.; Rouwet, D.; Caudron, C.; Marzocchi, W. Suparjan A new Bayesian Event Tree tool to track and quantify volcanic unrest and its application to Kawah Ijen volcano. Geochem. Geophys. Geosyst. 2016, 17, 2539-2555. [CrossRef]

25. Global Volcanism Program Website, Report on Ijen (Indonesia). Available online: https://volcano.si.edu/ volcano.cfm?vn=263350\# (accessed on 26 November 2019).

26. Caudron, C.; Girona, T.; Taisne, B.; Gunawan, H. Change in seismic attenuation as a long-term precursor of gas-driven eruptions. Geology 2019, 47, 632-636. [CrossRef]

27. Delmelle, P.; Bernard, A. Downstream composition changes of acidic volcanic waters discharged into the Banyupahit stream, Ijen caldera, Indonesia. J. Volcanol. Geotherm. Res. 2000, 97, 55-75. [CrossRef]

28. Palmer, S.C.J.; van Hinsberg, V.J.; McKenzie, J.M.; Yee, S. Characterization of acid river dilution and associated trace element behavior through hydrogeochemical modeling: A case study of the Banyu Pahit River in East Java, Indonesia. Appl. Geochem. 2011, 26, 1802-1810. [CrossRef]

29. Sumarti, S. Volcanic Pollutants in Hyperacid River Water Discharged from Ijen Crater Lake, East Java, Indonesia. Master's Thesis, Utrecht University, Utrecht, The Netherland, 1998.

30. Löhr, A.; Bogaard, T.; Heikens, A.; Hendriks, M. Natural Pollution Caused by the Extremely Acid Crater Lake Kawah Ijen, East Java, Indonesia. Environ. Sci. Pollut. Res. 2005, 12, 89-95. [CrossRef]

31. van Rotterdam-Los, A.M.D.; Vriend, S.P.; van Bergen, M.J.; van Gaans, R.F.M. The effect of naturally acidified irrigation water on agricultural volcanic soils. The case of Asembagus, Java, Indonesia. J. Geochem. Explor. 2008, 96, 53-68. [CrossRef]

32. van Hinsberg, V.; Berlo, K.; van Bergen, M.; Williams-Jones, A. Extreme alteration by hyperacidic brines at Kawah Ijen volcano, East Java, Indonesia I Textural and mineralogical imprint. J. Volcanol. Geotherm. Res. 2010, 198, 253-263. [CrossRef]

33. Rowe, G.; Brantley, S. Estimation of the dissolution rates of andesitic glass, plagioclase and pyroxene in a flank aquifer of Poás Volcano, Costa Rica. Chem. Geol. 1993, 105, 71-87. [CrossRef]

34. Africano, F.; Bernard, A. Acid alteration in the fumarolic environment of Usu volcano, Hokkaido, Japan. J. Volcanol. Geotherm. Res/ 2000, 97, 475-495. [CrossRef]

35. Berlo, K.; van Hinsberg, V.J.; Vigouroux, N.; Gagnon, J.E.; Williams-Jones, A.E. Sulfide breakdown controls metal signature in volcanic gas at Kawah Ijen volcano, Indonesia. Chem. Geol. 2014, 371, 115-127. [CrossRef]

36. Utami, S.B.; Hinsberg, V.J.; Ghaleb, B.; Pinti, D.L. Growth-zoned gypsum stalactite from the Kawah Ijen volcanic lake, Indonesia, records a $>40$-year record of volcanic activity. Bull. Volcanol. 2019, 81, 52. [CrossRef]

37. Casey, W.H.; Westrich, H.R.; Holdren, G.R. Dissolution rates of plagioclase at $\mathrm{pH}=2$ and 3. Am. Miner. 1991, 76, 211-217.

38. Parkhurst, D.L.; Appelo, C.A.J. User's guide to PHREEQC (Version 2): A computer program for speciation, batch-reaction, one-dimensional transport, and inverse geochemical calculations. Water Resour. Investig. Rep. 1999, 99, 312.

39. Bindeman, I.N.; Davis, A.M.; Drake, M.J. Ion microprobe study of plagioclase-basalt partition experiments at natural concentration levels of trace elements. Geochim. Cosmochim. Acta 1998, 62, 1175-1193. [CrossRef]

40. Bindeman, I.N.; Davis, A.M. Trace element partitioning between plagioclase and melt: Investigation of dopant influence on partition behavior. Geochim. Cosmochim. Acta 2000, 64, 2863-2878. [CrossRef]

41. Wood, B.J.; Blundy, J.D. Trace Element Partitioning under Crustal and Uppermost Mantle Conditions: The Influences of Ionic Radius, Cation Charge, Pressure, and Temperature. Treatise Geochem. 2003, 2, 395-424. 
42. Bédard, J.H. A catalytic delamination-driven model for coupled genesis of Archaean crust and sub-continental lithospheric mantle. Geochim. Cosmochim. Acta 2006, 70, 1188-1214. [CrossRef]

43. Putirka, K.D. Thermometers and Barometers for Volcanic Systems. Rev. Mineral. Geochem. 2008, 69, 61-120. [CrossRef]

44. Dare, S.A.S.; Barnes, S.-J.; Beaudoin, G. Variation in trace element content of magnetite crystallized from a fractionating sulfide liquid, Sudbury, Canada: Implications for provenance discrimination. Geochim. Cosmochim. Acta 2012, 88, 27-50. [CrossRef]

45. Lawson, C.L.; Hanson, R.J. Solving Least Squares Problems (Classics in applied mathematics); SIAM: Philadelphia, PA, USA, 1995; Volume 15, 337p.

46. Berlo, K.; van Hinsberg, V.J.; Suparjan; Gunawan, H. Using the composition of fluid seepage from the magmatic-hydrothermal system of Kawah Ijen volcano, Indonesia, as a monitoring tool. J. Volcanol. Geotherm. Res. 2020. in review.

(C) 2020 by the authors. Licensee MDPI, Basel, Switzerland. This article is an open access article distributed under the terms and conditions of the Creative Commons Attribution (CC BY) license (http://creativecommons.org/licenses/by/4.0/). 